\title{
4. PRELIMINARY RESULTS OF THE GALINAUTE CRUISE: DIVES OF THE SUBMERSIBLE NAUTILE ON THE WESTERN GALICIA MARGIN, SPAIN ${ }^{1}$
}

\author{
Gilbert Boillot ${ }^{2}$, Maria C. Comas ${ }^{3}$, Jacques Girardeau 4 , Jacques Kornprobst ${ }^{5}$, \\ Jean-Paul Loreau ${ }^{6}$, Jacques Malod ${ }^{7}$, Denis Mougenot ${ }^{2}$, and Michel Moullade ${ }^{8}$
}

\begin{abstract}
In 1986, the French submersible Nautile was used to investigate at depths of 3500 to $5500 \mathrm{~m}$ in the area west of Galicia (Spain) where the JOIDES Resolution had drilled 12 holes in 1985 during ODP Leg 103. Three different kinds of seafloor were investigated with the Nautile: (1) the Galicia passive margin, where crystalline continental basement and Paleozoic(?)-Mesozoic sediments outcrop; (2) a basaltic seafloor, interpreted as a piece of Cretaceous oceanic crust that is presently incorporated into the northern slope of Galicia Bank as a result of Eocene tectonics; and (3) an ultramafic seafloor, composed of serpentinized peridotite locally cut by dolerite dikes. The ultramafic rocks form a 100-km-long belt between North Atlantic oceanic crust to the west and thinned continental crust of the Galicia margin to the east.

New data from the Nautile dives complement and confirm some of the ODP Leg 103 results; they also force reassessment of some of the preliminary interpretations proposed by the Leg 103 shipboard scientific party.
\end{abstract}

\section{INTRODUCTION}

The passive continental margin west of Galicia (Spain) is characterized by a thin and discontinuous sedimentary cover. These conditions are favorable for studying local outcrops on the seafloor of the crystalline basement of the margin and the first sediments deposited on that basement; equivalent rocks are deeply buried under younger sediments on most other margins. Subsequent to Ocean Drilling Program (ODP) Leg 103 drilling on the Galicia margin in 1985 (see the Initial Reports of Leg 103; Boillot, Winterer, et al., 1987), we dove in the same region with the French submersible Nautile during the Galinaute cruise of the Nadir (21 May-2 July 1986). Nautile, with two pilots and one scientist aboard, is capable of operations to a maximum depth of $6000 \mathrm{~m}$. During the Galinaute cruise, we dove to depths ranging from 3500 to $5500 \mathrm{~m}$ at 15 different sites (Fig. 1), collecting 104 rock samples from the seafloor over a distance of $30 \mathrm{~km}$ (Boillot et al., 1986a). These new data complement the Leg 103 data.

The general scientific objectives of the Galinaute cruise were the same as those of ODP Leg 103. The Galicia margin was chosen for drilling and diving investigations in order to reconstruct the initial history of a passive margin and to understand the effects of horizontal stretching of the lithosphere during rifting as well as during the birth of a new ocean (the North Atlantic) between two continents (Newfoundland and Iberia) moving away from each other. The Galinaute cruise, scheduled only one year after Leg 103, aimed at three specific objectives:

\footnotetext{
${ }^{1}$ Boillot, G., Winterer, E. L., et al., 1988. Proc. ODP, Sci. Results, 103: College Station, TX (Ocean Drilling Program).

${ }^{2}$ Laboratoire de Géodynamique Sous-Marine, Villefranche-sur-Mer, France.

3 Instituto Andaluz de Geologiá Mediterránea, CSIC, Universidad de Granada, Granada, Spain.

${ }^{4}$ Laboratoire de Pétrologie Physique, Institut de Physique du Globe et Université de Paris VII, Paris, France.

5 Centre de Recherches Volcanologiques, Clermont-Ferrand, France.

${ }^{6}$ Laboratoire de Géologie, Muséum National d'Histoire Naturelle, Paris, France.

7 Département de Géologie Dynamique, Université Pierre et Marie Curie, Paris, France.

${ }^{8}$ Laboratoire de Géologie et Micropaléontologie Marines, Université de Nice, Nice, France.
}

1. To complete our knowledge of the initial history of the margin during the Triassic and Jurassic. Serious difficulties hampered coring sedimentary rocks of that age on Leg 103, and we hoped to recover the missing section by sampling normal fault escarpments visited with the Nautile.

2. To sample the ultramafic basement bounding the deep margin. Studies of a sample dredged in 1978 (Boillot et al., 1980) and of cores drilled at Site 637 (see "Site 637" chapter; Shipboard Scientific Party, 1987a) showed that upper mantle serpentinized peridotites crop out on the seafloor in a zone between the continental crust of the Iberian margin and the basaltic crust of the Atlantic Ocean. The Galinaute scientific party hoped to confirm that discovery by increasing the number of insitu observations at different localities and thereby developing a better understanding of the transition between the ultramafic seafloor and the adjacent continental and oceanic crusts.

3. To sample the "acoustic basement" overlying the S reflector. Seismic lines recorded on the deep Galicia margin (Fig. 2) show a strong reflector within the acoustic basement, labeled the "S" horizon by de Charpal et al. (1978). Interpretation of this reflector is controversial. It could be a detachment surface at the boundary between the basement and the overlying deformed sedimentary cover, as proposed by the Leg 103 scientific party (see "Site 640" chapter; Shipboard Scientific Party, 1987c). Alternatively, it could be the boundary between brittle and ductile crust, where listric normal faults root (Montadert et al., 1979), or some other intracrustal geophysical boundary (Boillot et al., 1980). By taking samples on fault escarpments from the "acoustic basement" overlying the S reflector, we hoped to constrain the interpretations of this enigmatic feature.

Most of these three objectives were achieved by the Galinaute cruise. In addition, the Nautile recorded unexpected data concerning the Atlantic oceanic crust close to the margin and the structure of the northwestern slope of the Galicia Bank. In this paper we present preliminary results of dive observations and the present state of post-cruise sample studies; further studies of the data are in progress at the time of this writing.

\section{MORPHOLOGIC AND STRUCTURAL SETTING OF THE DIVE SITES}

Taking the scientific objectives into account, we selected the dive sites on the basis of previously collected bathymetric and 


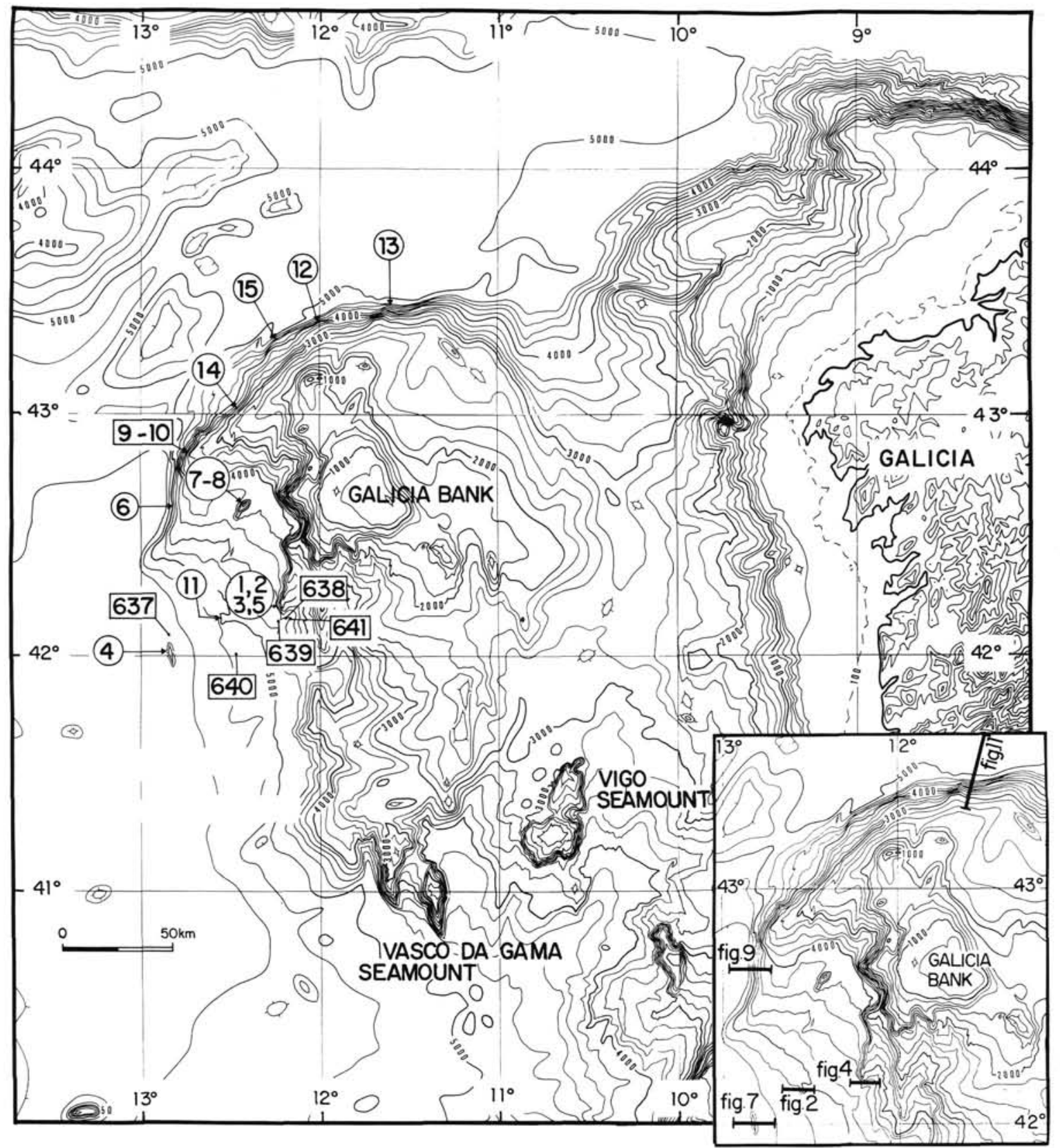

Figure 1. Locations of the 15 dive sites of the Galinaute cruise (circled) and the 5 drill sites of ODP Leg 103 (boxed) on the Galicia margin. Oceanic basaltic seafloor with pillow lavas was found at Sites 12, 13, and 15. Dive Sites 4, 6, 9, 10, and 14 are located on ultramafic seafloor, which consists of serpentinized peridotite locally cut by dolerite dikes (Site 14). The continental crystalline basement of this margin was sampled at Sites 7, 8, and 11; its sedimentary Mesozoic cover at Sites 2, 5, and 11; and possible Paleozoic sedimentary and volcanic rocks at Sites 1 and 2. During the Galinaute cruise, Nautile covered a distance of $30 \mathrm{~km}$ on the seafloor and collected 104 rock samples. Bathymetry after Lallemand et al. (1985); bathymetric contours in meters. Inset with the locations of seismic sections in Figures 2, 4, 7, 9, and 11.

seismic data. Escarpments with unstable loose sediments and with outcrops of basement or indurated sediments were located on Sea Beam maps (Groupe Transmarge, 1984; Lallemand et al., 1985; Sibuet et al., 1987). From the structural interpretation of the seismic data these escarpments can be classified into three categories:

1. Normal fault or transverse fault escarpments inherited from the Mesozoic rift (Sites 1, 2, 3, 5, 7, 8, and 11; Fig. 1). These escarpments are located on the passive margin, where the basement is continental. Normal and transverse faults of the rift, which now bound the tilted crustal blocks, have remained inactive since the late Aptian (see "Site 641" chapter; Shipboard Scientific Party, 1987d). Either the fault escarpments where the basement, pre-, and syn-rift sediments crop out were never buried by post-rift sediments or these unconsolidated sediments were removed by bottom currents, possibly during the Cenozoic.

2. The peridotite ridge extending along the deep margin (Site 4; Fig. 1). The generally buried peridotite ridge is locally free of sediments at Hill 5100 , where it could be directly observed and sampled from the Nautile. Seismic records show that 


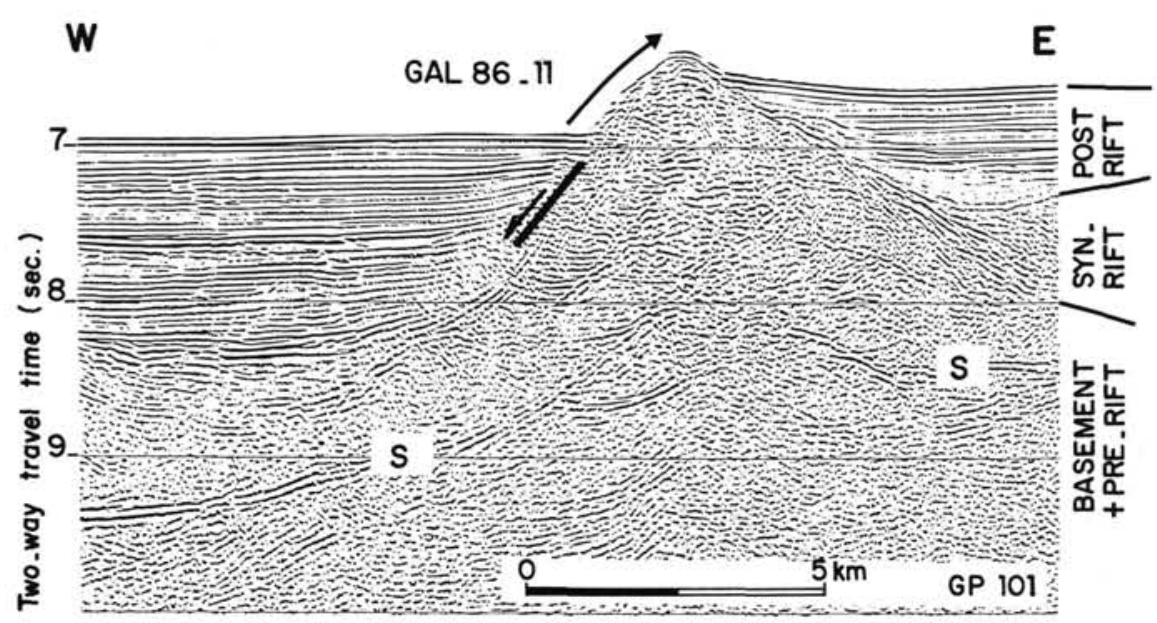

Figure 2. Institut Français du Pétrole (IFP) seismic line GP-101 across the tilted crustal block location of dive Site 11 (see Fig. 1). The $\mathrm{S}$ reflector divides the acoustical basement into two layers, the upper one consisting, at least partly, of granodioritic basement. (Profile by courtesy of L. Montadert.)

syn-rift sediments of pre-Albian age cover the eastern flank of the ridge; in other words, Hill 5100 has existed since at least 110 Ma.

3. Reverse fault and/or normal fault escarpments resulting from Cenozoic tectonics (Sites 6, 9, 10, 12, 13, 14, and 15; Fig. 1). To the north of $42^{\circ} 30^{\prime} \mathrm{N}$, the Mesozoic passive margin was deformed during the Paleogene. Former faults of the rift were remobilized then, and new structures probably were formed (Mauffret et al., 1978; Boillot et al., 1979). This tectonic event resulted from convergence between the Iberian and Eurasian plates and the correlated subduction of the oceanic lithosphere of the Bay of Biscay beneath Galicia (Grimaud et al., 1982). As a result of this subduction, the northern edge of the Galicia margin was uplifted, and consequently, the basement now crops out along the whole slope to the north and northwest side of Galicia Bank.

Dive sites were located on Hill 5100 (one site), at normal fault escarpments of the Mesozoic passive margin (seven sites), and at fault escarpments of the Cenozoic active margin, to the north of $42^{\circ} 30^{\prime} \mathrm{N}$ (seven sites). Experience showed that slopes dipping at least $15^{\circ}$ allowed basement and indurated sediments to crop out. In these locations, sampling was generally possible with the Nautile.

\section{MESOZOIC SEDIMENTARY COVER OF THE PASSIVE MARGIN}

Only a few samples were recovered from the Mesozoic sedimentary cover of the passive margin.

1. The only Mesozoic sample definitively dated by its microfauna was collected at Site 11 (Sample 86-11-4; see Appendix). It consists of a laminated, skeletal-rich lime mudstone, including radiolarians, thin pelecypod shells, and scarce and badly preserved calpionellids (among which Tintinnopsella carpathica is tentatively identified). The rock, which probably belongs to a pelagic turbidite sequence, is thus late Tithonian-Neocomian in age. The close proximity of where this limestone was sampled to where basement was sampled (Fig. 3) suggests that the limestone might form a veneer directly on the basement.

Dolomitized quartz-bearing carbonate rock was sampled at dive Site 7, about $50 \mathrm{~km}$ to the north of dive Site 11 (Fig. 1). This rock (Sample 86-7-3) shows the same laminated texture as Sample 86-11-4, including some calpionellid ghosts, and might be of the same stratigraphic origin. It was also sampled in the immediate vicinity of the basement and on the same tilted block as Sample 86-11-4.

Taking the uncertainty about the age of these samples into account, they can be correlated either with the Tithonian carbonates or with the Valanginian calpionellid marls drilled at ODP Site 639 (see "Site 639" chapter; Shipboard Scientific Party, 1987b). In either case, however, the facies are different. At Site 639, Tithonian carbonates with neritic components were deposited in shallow water, whereas the nonlaminated, pelagic calpionellid marls were probably deposited on the upper slope. Conversely, Galinaute Samples 86-11-4 and 86-7-3, taken $20 \mathrm{~km}$ to the west of Site 639 , suggest a pelagic-turbidite sequence deposited in the deeper environment of a sedimentary basin. This basin could have been at the axis of the Galicia margin continental rift, which had just developed at that time.

2. Tithonian and Lower Cretaceous rocks were probably also sampled at dive Sites 2 and 5 (Figs. 4 through 6), $6 \mathrm{~km}$ to the north of Site 639 and on the same normal fault escarpment. Samples collected from these sites are described according to their inferred stratigraphic order (see Appendix for detailed description):

Sample 86-2-7 is a light brownish gray dolomite, derived from packstone-grainstone limestone. Petrological characteristics and diagenetic evolution of the rock are identical that of the pre-Valanginian dolomite drilled at Site 639 (lithologic Unit IV, Site 639; Shipboard Scientific Party, 1987b).

Sample 86-2-8 consists of yellowish brown, carbonate-cemented, limonite-stained, laminated fine-grained sandstone. Faint cross- or parallel-laminations suggest that the sandstone is part of a turbidite. Strong similarity exists between this sample and the Neocomian sandstones recovered on Leg 103 in the interval from Samples 103-639A-4R, $10 \mathrm{~cm}$, to 103-639A-6R, $36 \mathrm{~cm}$ (lithologic Unit III, Site 639; Shipboard Scientific Party, 1987b).

Sample 86-5-3 consists of yellowish gray, poorly cemented; feldspathic lithic arenite sandstone. Except for a lack of terrestrial plant debris, this lithology is comparable to that of the Valanginian sandstones recovered in Hole 638B. Samples 86-5-1 and 86-5-2 (diorite and basalt, respectively) are pebbles sampled from a conglomeratic unit interbedded with the sandstone.

At approximately the same place as dive Sites 2 and 5, pieces of Tithonian limestone and numerous samples of unfossiliferous sandstone were previously collected from the seafloor by dredging (Mougenot et al., 1985). 


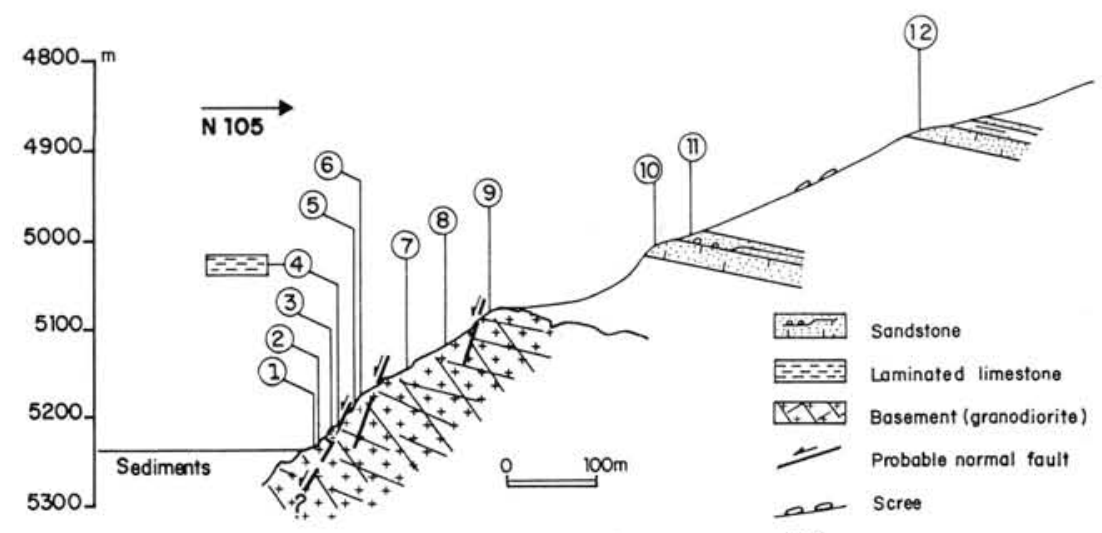

(1) Somple 86.11 .1

Figure 3. Schematic cross section at dive Site 11, showing the crystalline basement (mainly granodiorite) overlain by Tithonian-Berriasian micritic limestone (Sample 86-11-4) and undated sandstone (Samples 86-11-10 to 86-11-12).

None of the Galinaute samples described in this section contain microfossils with confident dates; therefore, we assign the samples to the Neocomian-Tithonian only by facies analogy with samples recovered at ODP Sites 638 and 639. Nevertheless, Galinaute data suggest that significant changes occur in the thickness of the Upper Jurassic carbonate platform. At dive Site 2 , the carbonates are about $70 \mathrm{~m}$ thick, according to our in-situ observations; at ODP Site 639, the same formation was inferred from drilling and background data to be $400-500 \mathrm{~m}$ thick (see Shipboard Scientific Party, 1987b). Even if the carbonate thickness calculated for Site 639 was overestimated (see the discussion on that point in the site chapter and in this volume by Loreau and Cros or Jansa et al.), such a difference is surprising. It might result from the existence of significant basement relief when the Tithonian transgression occurred. However, it is more likely that this thickness variation results from differential erosion of the summit of the carbonate deposits during the postJurassic, pre-Valanginian regression (Loreau and Cros, this volume). The dive sites were located where the pre-rift sequence is shallower (Fig. 1), and consequently, where there was possibly more erosion than at ODP Sites 638 and 639.

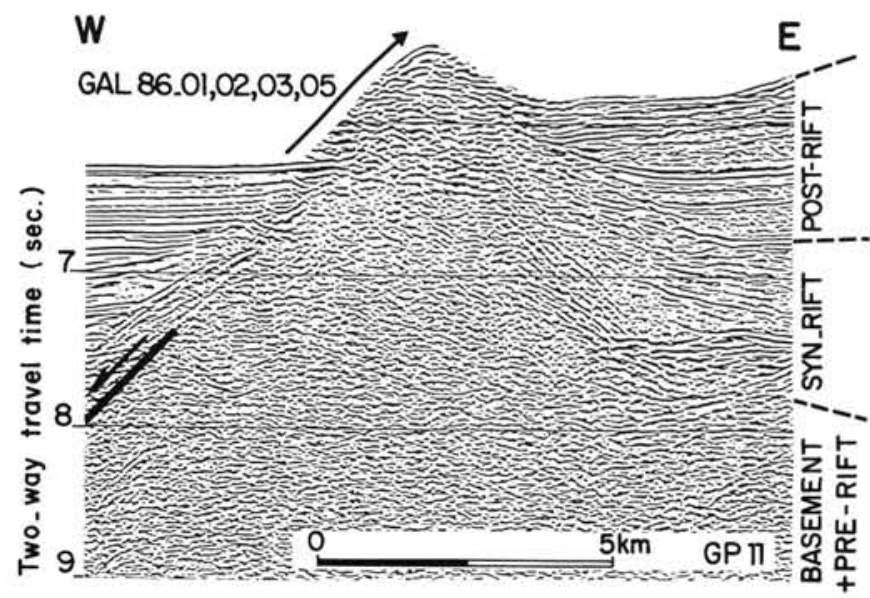

Figure 4. IFP seismic line GP-11 across the tilted crustal block location of dive Sites 1, 2, 3, and 5 (Fig. 1). The stratigraphy at these sites is in Figure 6. (Profile by courtesy of L. Montadert.)

\section{PROBLEMATIC VOLCANIC AND SEDIMENTARY SECTION UNDERLYING TITHONIAN CARBONATES}

The Nautile was used to sample a thick, barren pre-Cretaceous section of volcanic and sedimentary rocks, weakly metamorphosed or strongly diagenetic, that underlies the previously described Mesozoic sediments. The most complete and continuous section of these rocks is established by integrating the data from dive Sites 1, 2, and 3 (Figs. 4 through 6; see Appendix for detailed description).

1. A sequence at least $250 \mathrm{~m}$ thick and made up chiefly of volcaniclastic rocks with occasional, decameter-thick intervals of crinoid-bearing dolomite (Sample 86-1-3) was sampled at Site 1. Samples 86-1-1, 86-1-2, and 86-1-4 are dark gray or yellowish gray coarse- to fine-grained volcaniclastic sandstones with a brecciated texture. The recrystallized mineral paragenesis suggests a late hydrothermal metamorphism of the rocks.

2 . Overlying the volcaniclastic sequence, the lowermost part of the outcrop visited at dive Site 2 consists of dark gray, finegrained quartz wacke. The textural and mineral composition of this sandstone indicates low-grade (greenschist facies) metamorphism. These samples are equivalent to some of the rocks classified in the "problematic interval-mixed lithologies" drilled at Leg 103 Holes 639E and 639F (Shipboard Scientific Party, 1987b): Sample $86-1-4$ is similar to the rhyodacitic pieces, and Sample $86-2-1$ is comparable to the sandstone Sample 103-639F-1R-1, $0-8 \mathrm{~cm}$. In consideration of the facies and degree of metamorphism, we tentatively assign this sequence to the Late Paleozoic.

Further up in the section, we recovered crystalline dolomite overlain by sandstone (Fig. 6). Sample $86-2-2$ is a gray, extensively silicified dolomite, with ghosts of bivalves and echinoderms. Sample $86-2-3$ is a yellowish gray, quartz-bearing epigenetic dolomite. Sandstones (Samples 86-2-4, 86-2-5, and 86-2-6) include dark gray quartzose graywacke to subgraywacke. From their mineral and textural characters, these rocks are also comparable to some of the sandstone recovered at Holes 639E and 639F (e.g., Samples 103-639F-1R, 1-8 cm (Piece 4) and 103639E-3R-1, 18-21 cm; Shipboard Scientific Party 1987b), tentatively assigned to the Late Paleozoic by the Leg 103 scientific party.

3. Rocks sampled at dive Site 3 (Figs. 5 and 6) are red clay and sandy claystone, siltstone, and ferruginous crust. Sample 


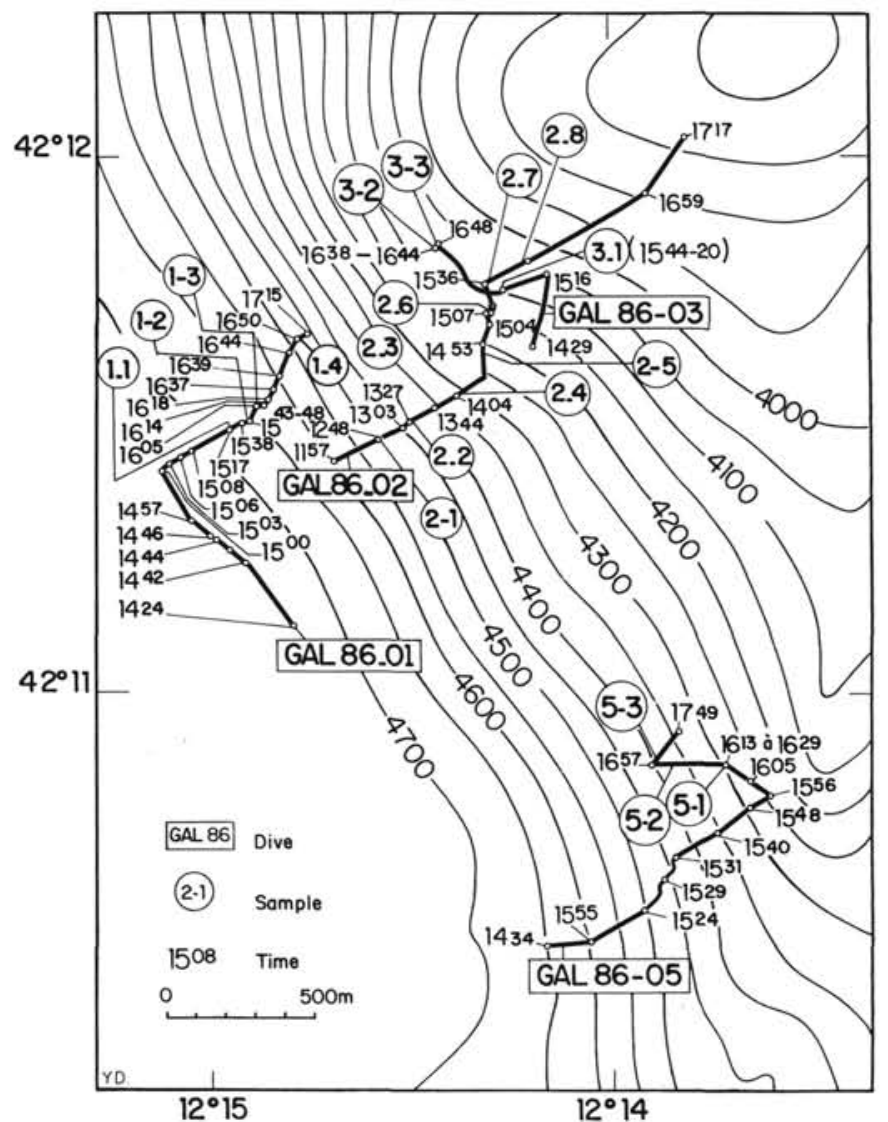

Figure 5. Location map of dives at Sites 1, 2, 3, and 5. Bathymetry in meters, after Sibuet et al. (1987).

86-3-1 is an indurated, variegated quartz-rich claystone. Preliminary X-ray analysis indicates large amounts of ferruginous oxides and the presence of illite, palygorskite, micas, and minor dolomite. Scattered, poorly sorted, coarse-grained angular quartz grains form the sandy fraction. Sample $86-3-3$ is a gray, laminated siltstone of angular quartz grains $(60 \%)$ within a finegrained matrix made of quartz and oriented mica. The dark red ferruginous crust (Sample 86-3-2) has a complex texture, including cavities infilled with red clay. Texture and composition suggest that the sample was recovered from a paleosoil. Its lithology resembles that of Sample 103-639E-4R, CC $(0-4 \mathrm{~cm})$, recovered within the Site 639 "problematic interval" and assigned to Late Paleozoic or Triassic by the Leg 103 scientific party.

Finally, we were able to observe and sample what is probably the weakly metamorphic sedimentary sequence that was recovered only as fragments or pebbles at Site 639 . At the dive sites this sequence is about $500 \mathrm{~m}$ thick and rests upon the volcaniclastic section, elements of which were also cored at Site 639. At this time, the geometric relation between these formations at the drilling and diving sites, $6 \mathrm{~km}$ apart, remains uncertain. In any case, the sedimentary sequence described in this section is beneath the carbonate formation assigned to the Tithonian. It underwent a thermal or hydrothermal event, which could explain the lack of organic matter and recognizable microfossils in the samples. Its age assignment to the Late Paleozoic, Triassic, or even Jurassic and its relation with the underlying volcaniclastic section remain as questions to be resolved by further investigation.

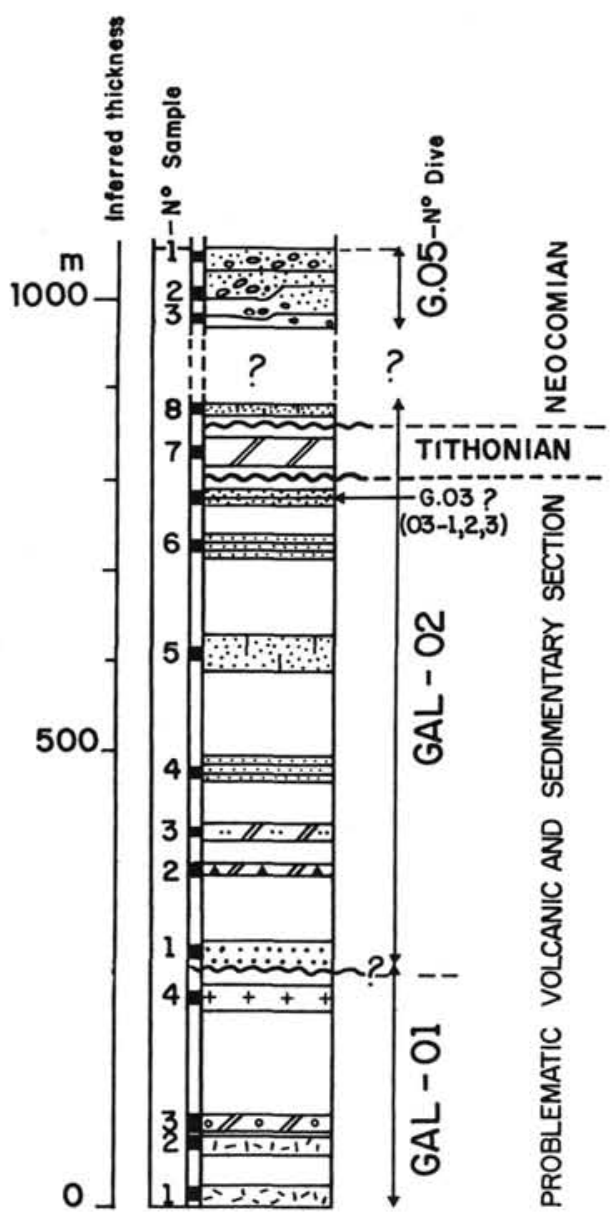

Figure 6. Composite $\log$ based on dive results at Sites 1, 2, 3, and 5. The investigated outcrop is on a normal fault escarpment (see Figs. 4 and 5). Lithology of sampled intervals: $86-5-1$ through $86-5-3=$ coarse-grained sandstone and conglomerate of probable Valanginian age; $86-2-8=$ fine-grained, laminated sandstone with carbonate cement of probable Neocomian age; $86-2-7$ = light brown-gray dolomite of Tithonian age; 86-3-1 through 86-3-3 = red and brown sandstone, silt, and clay, with ferruginous coating; 86-2-4 through 86-2-6 = fine-grained, thin-bedded sandstone, cemented by chlorite and sericite; $86-2-3=$ massive dolomite with ghosts of crinoids; $86-2-2=$ dolomite breccia, cemented by chert, sericite, and muscovite; $86-2-1$ = fine-grained sandstone, cemented by sericite and chlorite; 86-1-4 = dacite, more or less recrystallized; 86$1-3=$ bioclastic entrocal dolo-packstone; $86-1-1$ and $86-1-2=$ volcaniclastic, dacitic microbreccia. Thickness of the barren sedimentary sequence is possibly underestimated.

\section{CRYSTALLINE BASEMENT OF THE MARGIN AND INTERPRETATION OF THE S REFLECTOR}

At dive Sites 7, 8, and 11 (Fig. 1), several samples were recovered in situ on the western slope of the last tilted block of the margin (Figs. 1 and 3), in an area where the S reflector appears on the seismic records clearly (Fig. 2). At these sites, the basement is mostly composed of more or less deformed granite and granodiorite. Thus, the $\mathrm{S}$ reflector is located either within or beneath the thinned continental crust of the margin, as proposed by de Charpal et al. (1978) and Montadert et al. (1979), rather than at the base of syn-rift Mesozoic sediments, as suggested by the Leg 103 scientific party (Shipboard Scientific Party, 1987c). 
Drilling at Site 640 was abandoned with the bit only $70 \mathrm{~m}$ below the break-up unconformity, penetrating Lower Cretaceous turbidite beds. At dive Site 11 (Fig. 3), the granodiorite basement is covered by about $300 \mathrm{~m}$ of poorly sorted, coarse- to medium-grained barren sandstone and conglomerate. These sedimentary rocks contain detrital quartz, quartzite, feldspar, and mica, plus rock fragments, cemented by a sericite and ferruginous clay matrix. This sedimentary sequence is included in the acoustic basement (Fig. 2), as is the syn-rift sequence drilled at Site 640 . Although the Galinaute samples could be assigned to the syn-rift sequence as well as to a previously unknown pre-rift sequence, it is thus established that the acoustic basement can include clastic sediments that are difficult or impossible to distinguish from the crystalline basement on the seismic records. The misinterpretation of the drilling data at Site 640 results from the existence in the same acoustically incoherent unit of several geological formations of different origin that have the same acoustic impedance and character.

At dive Sites 7, 8, and 11 (granite and granodiorite) as well as at Site 1 (volcanic rocks), the continental basement outcropping on normal fault escarpments of the margin belongs to the upper part of the continental crust. During the Galinaute cruise, we never recovered samples derived from the granulite facies of the lower continental crust, except at Site 9, where we recovered a rounded block of charnockite.

\section{ULTRAMAFIC BASEMENT AT THE WESTERN EDGE OF THE GALICIA MARGIN}

One of the most important results of the Galinaute cruise deals with the distribution of peridotite at the base of the margin. Previously, this rock was recovered at only two sites: (1) Hill 5100 (see Shipboard Scientific Party, 1987a; Boillot et al., 1980), and (2) $60 \mathrm{~km}$ farther north, where a sample of serpentinite was dredged (Sibuet et al., 1987). During the Galinaute cruise, peridotites were sampled at other sites from north to south over a 100-km distance. Dives 4, 6, 9, 10, and 14 thus established that the Galicia margin is bordered to the west by a continuous belt where the seafloor consists of upper mantle rocks. These rocks are spinel or, more frequently, spinel and plagioclase diopsiderich harzburgites or lherzolites, sometimes rich in brown amphibole. At dive Site 14, 5- to 10-cm-thick pyroxenite layers (orthopyroxene + clinopyroxene + plagioclase) were sampled.

The peridotites have been plastically deformed, exhibiting shear zones slightly oblique to a primary foliation. At a later time, they were almost entirely serpentinized, then fractured and injected by veins of calcite. This evolution is identical to that of the peridotite drilled at Site 637 (Shipboard Scientific Party, 1987a; Girardeau et al., this volume).

The alteration and dip of the peridotites at Hill 5100 are slightly different from that of the peridotites to the north, along the western edge of the Galicia Bank. On the western side of Hill 5100 (Fig. 7), the peridotites are severely altered and almost entirely transformed into clay minerals. The foliation, observed from aboard Nautile, dips by about $15^{\circ}$ to the northeast (Fig. 8 ). At dive Sites 6, 10, and 14, rocks are fresh serpentinite, without clay minerals, and the dip of the foliation increases to as much as $70^{\circ}$. These differences probably result, at least in part, from Pyrenean tectonics. To the south at the base of the passive margin, the peridotite has been exposed on the seafloor since at least $110 \mathrm{Ma}$; conversely, at Sites 6, 9, 10, and 14, it has cropped out only since the Eocene or Oligocene, 40 or $35 \mathrm{Ma}$ ago, as a result of the convergence between the Iberian and Eurasian plates and associated subduction. The northern and northwestern edge of the Galicia Bank was fractured, and the bank itself was uplifted several kilometers. Nevertheless, the initial structure of the peridotite ridge was preserved on its continental side; for example, seismic lines recorded at dive Site 6 (Fig. 9) show syn- and post-rift strata covering the ridge, as observed on the east ern side of the Hill 5100 (Fig. 7). If we consider only the Meso zoic structure, there are but minor differences between the shape structure, and age of the peridotite ridge between Sites 4 and 14

Though not observed at the other dive sites, dolerite dikes that cut the peridotite at Site 14 may represent the root of a silldike complex, as known in typical ophiolitic sequences.

\section{BASALTIC BASEMENT TO THE NORTH OF GALICIA BANK}

On the northern side of the Galicia Bank, where we expected to find either peridotite or continental basement, we found basaltic rocks with classic pillow and tube structures (Sites 12, 13, and 15; Fig. 10). The basalts have MORB characteristics (cesium/samarium ratio < 1) and resemble the upper part of an oceanic crust.

Seismic records (Fig. 11) show that basalts crop out along the north and northwest side of a basement ridge, which was buried by sediments on the other (continental) side. According to the regional acoustic stratigraphy (Groupe Galice, 1979), these sediments are post-rift (i.e., Cretaceous-Cenozoic) in age. Sedimentary rocks that overlie the basalts were sampled at dive Site 15 and are consistent with this proposed age. These rocks consist of pelagic red-brown clays containing few primitive agglutinated benthic foraminifers plus some Cenozoic ichthyoliths. They resemble the Cretaceous-Paleogene sediments drilled at Sites 640 and 641 during Leg 103 (Shipboard Scientific Party, 1987c, 1987d). Taking all of these data into account, we assume that the basalts are Cretaceous in age, contemporaneous with the process of oceanic accretion in the western approaches of the Bay of Biscay.

The basaltic seafloor investigated with the Nautile is presently at water depths of $4500-3500 \mathrm{~m}$, which is at least 1 or 2 $\mathrm{km}$ shallower than beneath the sediments of the Biscay Abyssal Plain. Therefore, the seafloor has been uplifted along the Galicia Bank by Eocene tectonics, as has the peridotite ridge to the south (see the preceding). Nevertheless, the structural setting at dive Sites 12,13 , and 15 on the edge of the Galicia Bank is comparable with that of Deep Sea Drilling Project Leg 80, Site 551, drilled close to the ocean/continent crustal transition at the base of Goban Spur (de Graciansky, Poag, et al., 1985). The Leg 80 Scientific Party proposed two possible interpretations for the oceanic basalts cored on a basement ridge overlooking the Atlantic Abyssal Plain: either the ridge is made up of the first oceanic crust formed between Goban Spur and Flemish Cap margin or it corresponds to the former continental rift axis covered by tholeiitic basalt flows during the last stage of its evolution. The same alternative interpretations could be proposed for the Mesozoic basement ridge where basaltic floor was observed from the Nautile at the northern side of Galicia Bank.

\section{DISCUSSION AND CONCLUSIONS}

According to the preliminary interpretations proposed in this paper, the Galinaute scientific party observed three types of seafloor, juxtaposed over a distance of less than $100 \mathrm{~km}$ : (1) continental basement (Sites 7, 8, and 11), (2) oceanic basaltic rocks (Sites 12, 13, and 15), and (3) serpentinized peridotite (Sites 4, $6,9,10$, and 14). The question of the structural relationships between these three kinds of seafloor remains to be solved.

The transition between the ultramafic and continental seafloor was not observed. Except for two allochthonous blocks made of charnockite, samples from the continental basement of the deep Galicia margin belong to the upper part of the continental crust (dive Sites 7, 8, and 11 and dredge hauls; see Capdevila and Mougenot, this volume). Though the whole continental basement was not sampled with the Nautile, our observations and recovery could suggest that the lower (granulitic) 


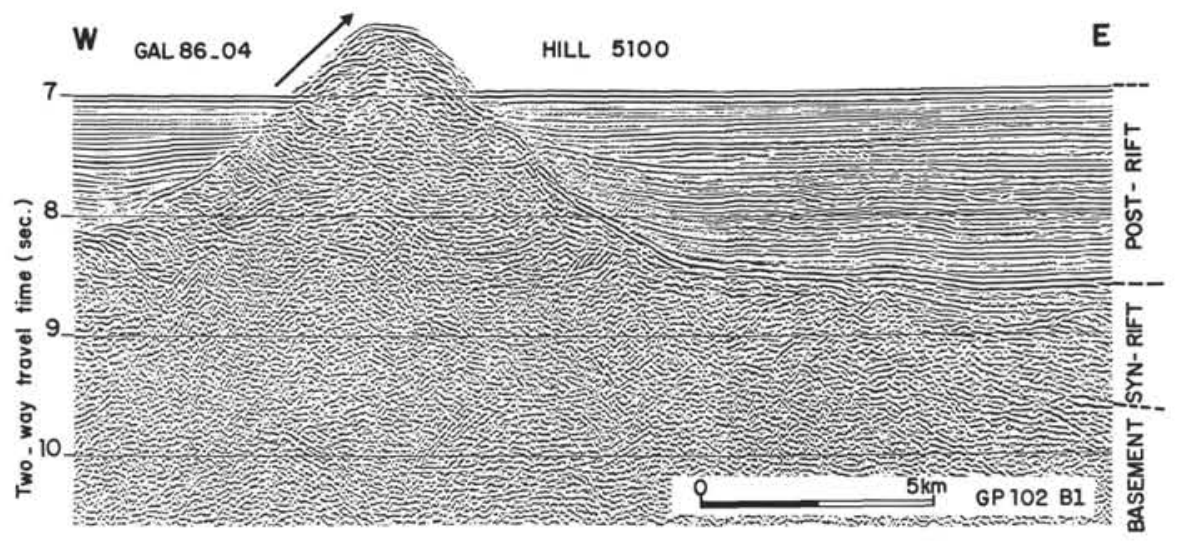

Figure 7. IFP seismic line GP-102 B1 across Hill 5100 location of dive Site 4 (Fig. 1). Lower Cretaceous syn-rift sediments overlap the eastern side of the buried ridge of serpentinized peridotite. (Profile by courtesy of L. Montadert.)

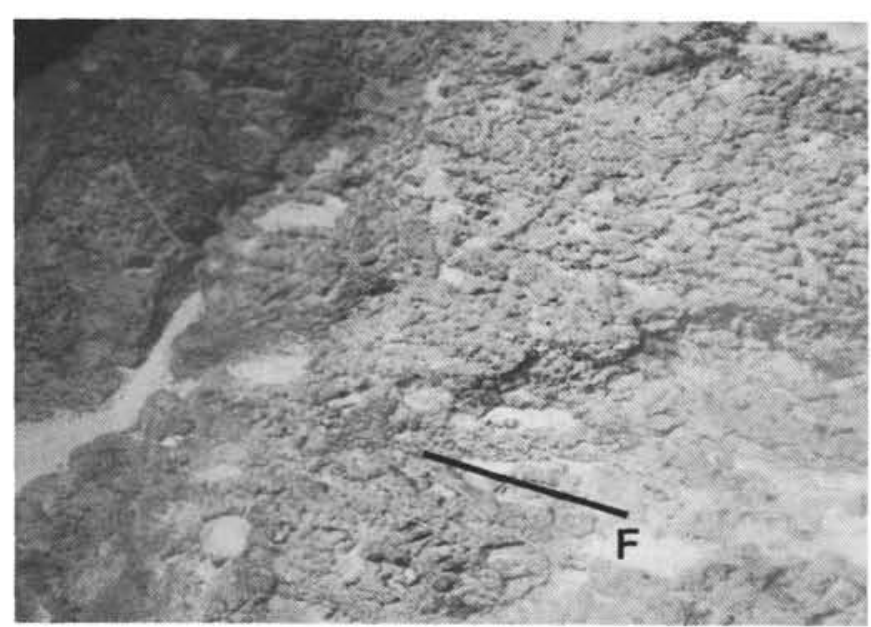

Figure 8. Peridotite foliation (F) on the western flank of Hill 5100, at dive Site 4 . The foliation dip is about $15^{\circ}$ to the northeast. Water depth $=5300 \mathrm{~m}$.

continental crust is missing and consequently, that the two types of basement (ultramafic and continental) are separated by a major tectonic feature. This feature could correspond to the detachment fault postulated by the Leg 103 scientific party to account for the structural evolution of peridotites drilled at Site 637 (Boillot et al., 1986b, 1987).

To the north of the Galicia Bank, the basaltic oceanic crust can be directly in contact with the continental crust of the margin, as at Goban Spur (de Graciansky, Poag, et al., 1985), or separated from the continental basement by a possible northeastward extension of the peridotite ridge. The transition between the peridotite ridge observed from dive Sites 4 through 14 to the basement ridge covered by basalt, at least on its northern side (dive Sites 12,13, and 15), remains unclear. To the west and to the north of Galicia Bank, the two margin segments where these different ocean/continent crustal transitions occur were parts of two different continental rifts before the Albian. Thus, it is not surprising that the initial ocean-spreading process differed in the two areas.

Most of the sedimentary samples recovered from the Nautile are of uncertain age, because of the extreme rarity or absence of microfauna. However, at dive Sites 2 and 5 we found elements of the pre- and syn-rift sequences (carbonate and clastic sedi- ments, respectively) that were drilled at Sites 638 and 639. Beneath the carbonate, we also sampled a thick $(500-\mathrm{m})$ weakly metamorphosed section, which could be assigned either to the Late Paleozoic, Triassic, or Jurassic. This section, in turn, rests on weakly metamorphosed and deformed dacitic and volcaniclastic rocks, including dolomite beds of marine origin. Whether the volcanic rocks are part of the overlying clastic section or are older and separated by an unconformity is yet unknown. In any case, detrital sediments, whether associated or not with felsic volcanics and underlying the Tithonian carbonates, may suggest that the Galicia margin underwent an initial extensional event that predated the Early Cretaceous rifting documented by Leg 103.

In conclusion, the Galinaute cruise permitted us to acquire new stratigraphic information on the history of the margin, which complements the data from ODP Leg 103. However, the most fundamental results from the dives concern the basement and its relation to the oceanic crust of the Atlantic Ocean. It is now established from the results of Leg 103 and Galinaute cruise that mantle rocks (peridotites) constitute the seafloor between the oceanic crust of the Atlantic and the thinned continental crust of the western Iberia margin (Fig. 12). This observation places new constraints on models of horizontal stretching of the lithosphere, tectonic denudation of the upper mantle, and seafloor spreading. With regard to ancient oceans, it also permits better understanding of certain peridotite nappes now incorporated in folded belts.

\section{ACKNOWLEDGMENTS}

We thank the Spanish government, which permitted the Galinaute cruise off the Galicia coast; the French organizations of IFREMER and CNRS, which supported the cruise and its preparation; the captain and the crew of the O.S. Nadir; the chief, pilots, and technical team of the Nautile; C. Müller, J. Taugourdeau-Lantz, and P. D. Doyle, who conducted to the nannofossil, pollen, and ichthyolith studies, respectively; and R. P. Freeman-Lynde and P. C. de Graciansky for their useful corrections, criticisms, and suggestions.

This work was supported by IFREMER, Université Pierre et Marie Curie, and CNRS (grant no. 1433 of the ATP Géologie et Géophysique des Océans). Contribution no. 426 of the Groupe d'Etude de la Marge Continentale.

\section{REFERENCES}

Boillot, G., Auxiètre, J. L., Dunand, J. P., Dupeuble, P. A., and Mauffret, A., 1979. The northwestern Iberian margin: a Cretaceous passive margin deformed during Eocene. In Talwani, M., Hay, W., Ryan, W.B.F. (Eds.), Deep Drilling Results in the Atlantic Ocean: Continental Margins and Paleoenvironment: Am. Geophys. Union, Maurice Ewing Ser., 3:138-153. 
Boillot, G., Comas, M. C., Girardeau, J., Kornprobst, J., Loreau, J.-P., Malod, J., Mougenot, D., and Moullade, M., 1986a. Fonds sousmarins basaltiques et ultramafiques au pied d'une marge stable. Résultats préliminaires de la campagne Galinaute (plongées du submersible Nautile à l'ouest de l'Espagne). C. R. Acad. Sci. Ser. 2, 303:1719-1724.

Boillot, G., Grimaud, S., Mauffret, A., Mougenot, D., Kornprobst, J., Mergoil-Daniel, J., and Torrent, G., 1980. Ocean-continent boundary of the Iberian margin: a serpentinite diapir west of the Galicia Bank. Earth Planet. Sci. Lett., 48:23-34.

Boillot, G., Recq, M., Winterer, E. L., Meyer, A. W., Applegate, J., Baltuck, M., Bergen, J. A., Comas, M. C., Davies, T. A., Dunham, K., Evans, C. A., Girardeau, J., Goldberg, D. G., Haggerty, J., Jansa, L. F., Johnson, J. A., Kasahara, J., Loreau, J.-P., Luna-Sierra, E., Moullade, M., Ogg, J., Sarti, M., Thurow, J., and Williamson, M., 1986b. Amincissement de la croûte continentale et dénudation tectonique du manteau supérieur sous les marges stables: à la recherche d'un modèle-L'exemple de la marge continentale de la Galice. Bull. Cent. Rech. Explor. Prod. Elf Aquitaine, 10:95-104.

1987. Tectonic denudation of the upper mantle along passive margins: a model based on drilling results (ODP Leg 103, western Galicia margin, Spain). Tectonophysics, 132:335-342.

Boillot, G., Winterer, E. L., et al., 1987. Proc. ODP, Init. Repts., 103: College Station, TX (Ocean Drilling Program).

de Charpal, O., Guennoc, P., Montadert, L., and Robert, D. G., 1978. Rifting, crustal attenuation and subsidence in the Bay of Biscay. $\mathrm{Na}$ ture, 275:706-711.

de Graciansky, P., Poag, C. W., et al., 1985. Init. Repts. DSDP, 80: Washington (U.S. Govt. Printing Office).

Grimaud, S., Boillot, G., Collette, B., Mauffret, A., Miles, P. R., and Roberts, D. B., 1982. Western extension of the Iberian-European plate boundary during the Early Cenozoic (Pyrenean) convergence: a new model. Mar. Geol., 45:63-77.

Groupe Galice, 1979. The continental margin off Galicia and Portugal: acoustical stratigraphy, dredge stratigraphy and structural evolution. In Sibuet, J.-C., Ryan, W.B.F., et al., Init. Repts. DSDP, 47, Pt. 2: Washington (U.S. Govt. Printing Office), 633-662.

Groupe Transmarge, 1984. Levé bathymétrique à l'aide du sondeur multifaisceaux "Sea-Beam", du versant septentrional du Banc de Galice (marge continentale ouest-ibérique). C. R. Acad. Sci. Ser. 2, 299:115-120.

Lallemand, S., Mazé, J. P., Monti, S., and Sibuet, J.-C., 1985. Présentation d'une carte bathymétrique de l'Atlantique nord-est. C. $R$. Acad. Sci. Ser. 2, 300:145-149.

Mauffret, A., Boillot, G., Auxiètre, J. L., and Dunand, J. P., 1978. Evolution structurale de la marge continentale au nord-ouest de la Péninsule ibérique. Bull. Soc. Geol. Fr., 20:375-388.

Montadert, L., de Charpal, O., Roberts, D., Guennoc, P., and Sibuet, J.-C., 1979. Northeast Atlantic passive continental margin: rifting and subsidence processes. In Talwani, M., Hay, W., Ryan, W.B.F. (Eds.), Deep Drilling Results in the Atlantic Ocean: Continental Margins and Paleoenvironment: Am. Geophys. Union, Maurice Ewing Ser., 3:154-186.

Mougenot, D., Capdevila, R., Palain, C., Dupeuble, P. A., and Mauffret, A., 1985. Nouvelles données sur les sédiments anté-rift et le socle de la marge continentale de Galice. C. R. Acad. Sci. Ser. 2, 301: 323-328.

Shipboard Scientific Party, 1987a. Site 637. In Boillot, G., Winterer, E. L., et al., Proc. ODP, Init. Repts., 103: College Station, TX (Ocean Drilling Program), 123-219.

1987b. Site 639. In Boillot, G., Winterer, E. L., et al., Proc. ODP, Init. Repts., 103: College Station, TX (Ocean Drilling Program), 409-532.

1987c. Site 640. In Boillot, G., Winterer, E. L., et al., Proc. ODP, Init. Repts., 103: College Station, TX (Ocean Drilling Program), 533-569.

1987d. Site 641. In Boillot, G., Winterer, E. L., et al., Proc. ODP, Init. Repts., 103: College Station, TX (Ocean Drilling Program), 571-649.

Sibuet, J.-C., Mazé, J. P., Amortila, P., and Le Pichon, X., 1987. Physiography and structure of the western Iberian continental margin off Galicia, from Sea Beam and seismic data. In Boillot, G., Winterer,
E. L., et al., Proc. ODP, Init. Repts., 103: College Station, TX (Ocean Drilling Program), 77-97.

Date of initial receipt: 10 February 1987

Date of acceptance: 10 August 1987

Ms 103B-118

\section{APPENDIX \\ Petrographic Summary of Selected Samples Recovered During the Galinaute Cruise}

M. C. Comas

Samples 86-1-1, 86-1-2, and 86-1-4

Dark gray or yellowish gray coarse- to fine-grained volcaniclastic sandstones with a brecciated texture. These sandstones are composed of angular quartz, feldspar (mainly albite), and polycrystalline quartz grains within a fine-grained matrix of quartz, feldspar, biotite, chlorite, epidotite, clinozoisite, white micas, and opaques. Volcanic rock fragments and some sedimentary quartz grains are also present. Angular quartz grains show strong undulatory extinction and fracturing. The rocks are locally recrystallized and silicified, showing a network of quartz veins. Compositionally and texturally, these samples represent a dacitic (calcalkaline) volcaniclastic and/or volcanisedimentary sequence. The recrystallized mineral paragenesis suggests a later hydrothermal alteration of the volcaniclastic rocks.

\section{Sample 86-1-3}

Medium-sized crystalline yellowish-light brown dolomite with dark gray skeletal remains ( $70 \%$ of the rock). The original limestone was probably a skeletal packstone or grainstone with bioclasts, consisting chiefly of echinoderm debris and thin shells of bivalves. Epigenetic dolomitization or weak metamorphism created the equant dolorhombohedron mosaic. Intercrystalline porosity is filled by iron oxides; minor detrital quartz $(<1 \%)$ is present (Pl. 1, Fig. 1).

\section{Sample 86-2-1}

Dark gray, fine-grained quartz wacke. The framework $(75 \%$ of the rock) consists of quartz $(87 \%)$, feldspar $(4 \%)$, and detrital muscovite and biotite $(8 \%)$. The original clay matrix ( $18 \%$ of the rock) has been transformed to authigenic micas, mainly chlorite and oxichlorite. Accessory minerals make up 2\% of the rock. Quartz cement ( $5 \%$ of the rock) is present, and sutured boundaries and overgrowth of quartz grains occur. Cementation is by intercrystalline growth between authigenic micas and quartz grains. The textural and mineral composition of this sandstone indicates that it has undergone low-grade (low greenschist) metamorphism (Pl. 2, Figs. 1 and 2).

\section{Sample 86-2-2}

Gray, extensively silicified, fine-crystalline, paraconglomeratic dolomite. Rounded dolomite clasts (maximum diameter $=1.5 \mathrm{~cm}$ ) and large bioclasts form $25 \%$ of the rock and are dispersed within a cherty matrix. The matrix is composed of carbonate $(5 \%)$, white micas $(15 \%)$, chert $(78 \%)$, and minor iron oxides $(2 \%)$, showing convolute lamination. Inside the dolomite clasts, ghosts of bivalves and echinoderms can be recognized. A small percentage of detrital quartz is also present. The original lithology was probably a clayey, pebbly lime mudstone that later silicified and dolomitized (Pl. 1, Figs. 2 and 3).

\section{Sample 86-2-3}

Yellowish gray epigenetic dolomite, made up of an equant-rhombohedron mosaic of poorly zoned, fine dolomite crystals with recognizable ghosts of crinoids and bivalves. Ferruginous impurities have been segregated from these crystals. Fine-grained quartz $(5 \%)$ is dispersed throughout. The rock appears fractured and crisscrossed by stylolitic seams (PI. 1, Fig. 4),

\section{Samples $86-2-4,86-2-5$, and $86-2-6$}

These three samples are lithologically homogenous, consisting of dark gray quartzose graywackes (Samples 86-2-4 and 86-2-5) and sub- 


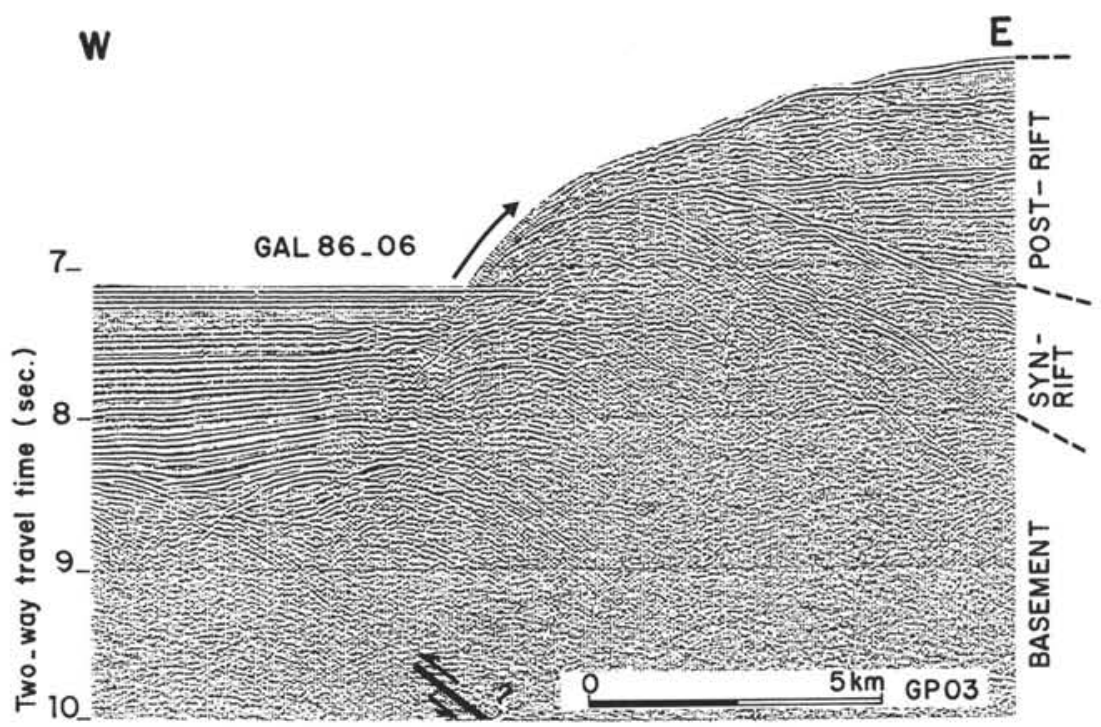

Figure 9. IFP seismic line GP-03 across the western slope of the Galicia Bank at dive Site 6 (Fig. 1). Lower Cretaceous syn-rift sediments onlap the eastern side of the peridotite ridge. The dive was on the western side of a fault escarpment resulting from Pyrenean tectonics. (Profile by courtesy of L. Montadert.)

graywackes (Sample 86-2-6). Yellowish, matrix-rich streaks lend a heterolithic aspect to these rocks. The framework is composed of poorly sorted, very angular quartz and quartzite $(60 \%-80 \%$ of the rock), feldspar $(10 \%-20 \%)$, detrital biotite and muscovite $(3 \%-5 \%)$, and metapelites $(<10 \%)$. The matrix $(25 \%-55 \%$ of the rock) consists of unoriented fine-grained white micas and subordinate authigenic chlorite. A small number of grain-to-grain contacts and moderate packing density occur. Sand-sized grains are isolated by smaller fractions, and intergrowths of sericite and chlorite are welded to the unstable margin of detrital quartz. The very angular quartz (splintered quartz) with corrosion gulfs suggests a volcaniclastic origin for some of the framework components. Accessory minerals are zircon, tourmaline, and opaques; Sample $86-2-4$ is particularly rich (up to $3 \%$ ) in idiomorphic zircon and tourmaline (Pl. 2, Figs. 3-6).

\section{Sample 86-2-7}

Light brownish gray, coarse-crystalline, sucrosic, epigenetic dolomite. Ghosts of echinoderms, bivalves, and a rounded clast can be recognized. The texture indicates that the original carbonate was either a lime grainstone or a lime packstone. Dirty, zoned dolomite rhombs line the bioclasts and intraclasts. Open intercrystalline pores are lined by baroque dolomite. Small fractures, showing replacement by clear dolomite, crosscut the rock and predate the last stage of dolomitization (dolomite crystal boundary across fracture walls) (Pl. 3, Fig. 1).

\section{Sample 86-2-8}

Limonite-stained, yellowish brown, carbonate-cemented, laminated fine-grained sandstone. The framework ( $70 \%$ of the rock) is essentially

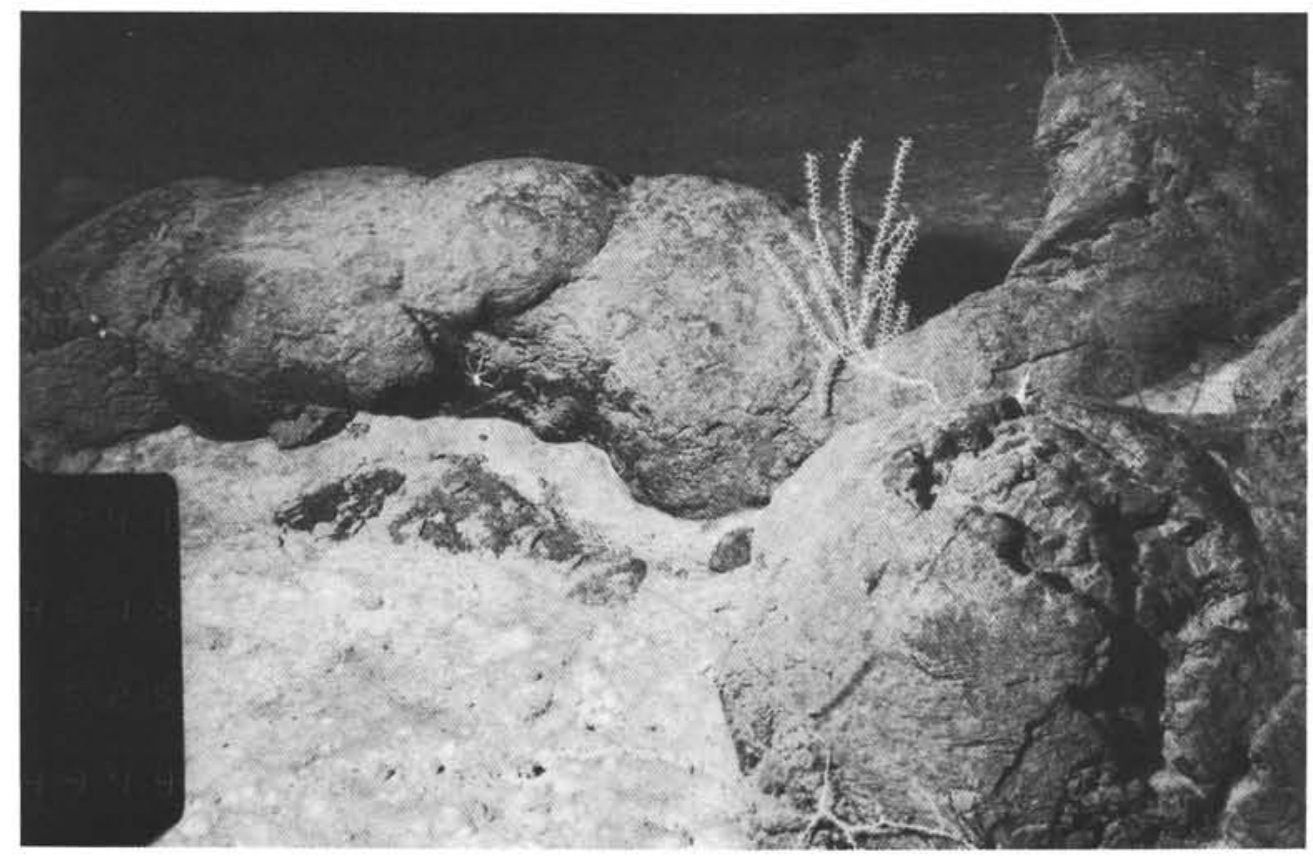

Figure 10. Tubes and pillows observed at dive Site 15, to the north of Galicia Bank (Fig. 1). The basaltic seafloor probably belongs to the upper part of an oceanic crust. Water depth $=4500 \mathrm{~m}$. 
made up of quartz $(>85 \%)$ and minor quantities of feldspar $(<10 \%)$, and mica and detrital carbonate grains $(<5 \%)$. The cement $(25 \%$ of the rock) is formed by equant sparite. Opaque ferruginous minerals constitute $5 \%$ of the rock. Solution of silica and its extensive replacement by carbonate are revealed by the extreme irregularity of the quartz-grain boundaries (corroded margins) and ghost remains of quartz within the calcite mosaic. Parallel and faint cross-lamination suggests the sandstone forms part of a turbidite (PI. 3, Figs. 2 and 3).

\section{Sample 86-3-2}

Dark red ferruginous crust with a complex texture. Preliminary petrographic studies indicate that this sample consists mainly of iron oxides, authigenic recrystallized chlorite, and ferroan chlorite, with subordinate detrital fine-grained quartz and mica. Cavities are filled with red clay (illite and palygorskite). Fragments of dolomite crusts are also present. The texture and composition of this sample suggest that it is a paleosoil (Pl. 3, Fig. 4).

\section{Sample 86-5-3}

Yellowish gray, poorly cemented feldspathic lithic arenite. The framework ( $70 \%$ of the rock) consists of quartz and quartzite grains $(81 \%)$, feldspar $(11 \%)$, metapelites $(5 \%)$, and detrital biotite $(3 \%)$. The cement ( $20 \%$ of the rock) is made up by equant dolosparite. Also present are small quantities of micaceous sericite-rich matrix (10\%) (Pl. 4, Fig. 1).

\section{Sample 86-7-3}

Gray, fine-grained dolomite, containing $5 \%$ silt-sized detrital quartz grains. The rock shows parallel lamination and graded bedding structures with quartz grain concentration at the base. Dolomitization has not obliterated the original grain size, and some replacement of quartz by dolomite exists. Idiomorphic pyrite grains are scattered throughout.
The texture and structure in this sample suggest that the original sediment was a thin-bedded carbonate turbidite (Pl. 4, Fig. 2).

\section{Sample 86-8-5}

Red, moderately sorted, fine-grained, arkosic arenite. The framework ( $>85 \%$ of the rock) consists of rounded to subrounded quartz and quartzite grains $(62 \%)$, feldspar $(32 \%)$, and rock fragments $(6 \%)$. Cement ( $<10 \%$ of the rock) is mostly quartz overgrowths with minor amounts of iron oxides. Inside the quartz grains, boundaries between detrital cores and overgrowths are marked by iron oxide coating. Much pressure solution and large grain-to-grain contacts are present. Accessory minerals are muscovite, authigenic chlorite, and zircon $(<5 \%$ of the rock). Petrological features suggest that this sample has undergone very high diagenetic or low-grade metamorphic processes (Pl. 4, Fig. 3).

\section{Sample 86-11-4}

Laminated, skeletal-rich lime mudstone. Pelagic bioclasts (radiolarians, thin pelecypod shells, and poorly preserved calpionellids) are dispersed within a clayey micrite matrix. Parallel lamination is marked by fossil concentrations, testifying to current activity. Texture and fossil content indicate a pelagic basinal sedimentary environment. According to calpionellid data, this facies is probably late Tithonian-Neocomian in age (Pl. 4, Fig. 4).

\section{Sample 86-11-10 and 86-11-11}

Yellowish brown, coarse-grained, poorly sorted, poorly cemented litharenite (Sample 86-11-10) and subarkosic arenite (Sample 86-11-11). The angular to subrounded framework ( $>85 \%$ of the rock) is made up of quartz and quartzite grains $(55 \%-70 \%)$, feldspar (10\%-30\%), rock fragments (igneous, metamorphic, and sedimentary; $5 \%-30 \%$ ), and minor detrital micas $(<5 \%)$. Quartz cement plus micaceous-ferruginous matrix constitute less than $15 \%$ of the rock. (Pl. 4, Figs. 5 and 6).

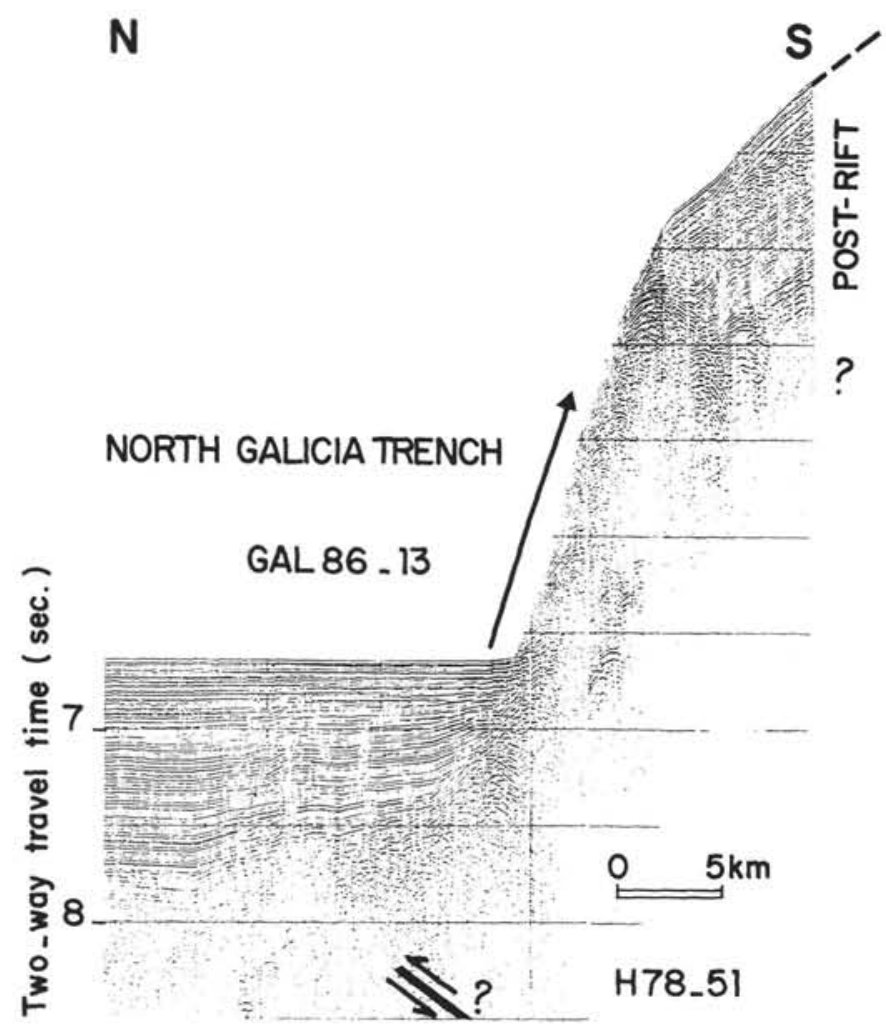

Figure 11. Seismic line H78-51 across the northern wall of Galicia Bank at dive Site 13. Nautile sampled oceanic basalts that cover the northern side of a basement ridge buried by Cretaceous and Cenozoic sediments on its southern side. The outcrop visited by Nautile is probably, at least in part, a Cenozoic fault escarpment. 


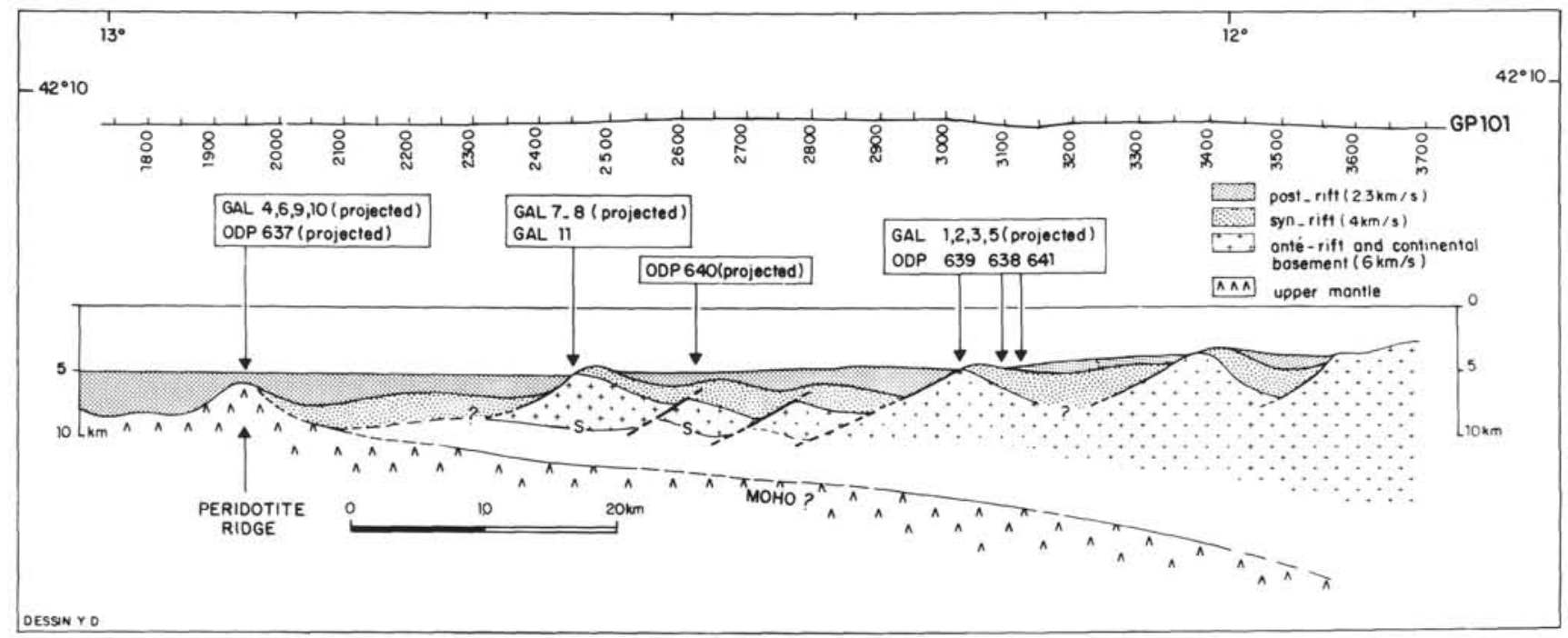

Figure 12. Synthetic cross section of the passive margin off Galicia, along $42^{\circ} 10^{\prime} \mathrm{N}$ (Fig. 1). This cross section is based on interpretation of IFP seismic line GP-101 and Leg 103 and Galinaute cruise data. The location of the Moho is delineated assuming isostatic equilibrium and densities of 2.8 and 3.3 for the thinned continental crust and upper mantle, respectively. 


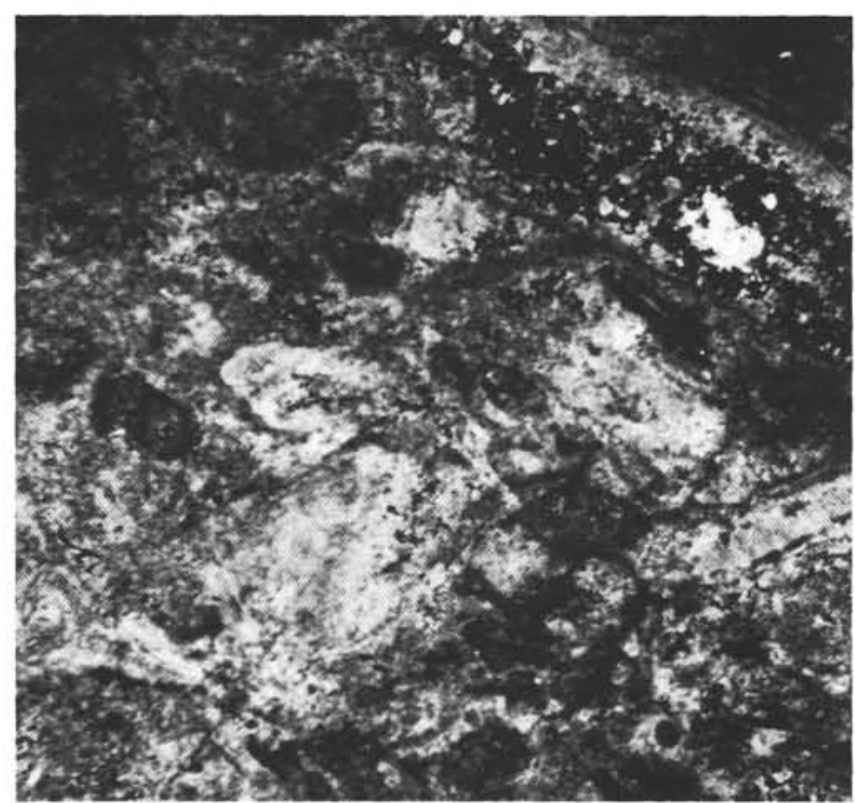

1

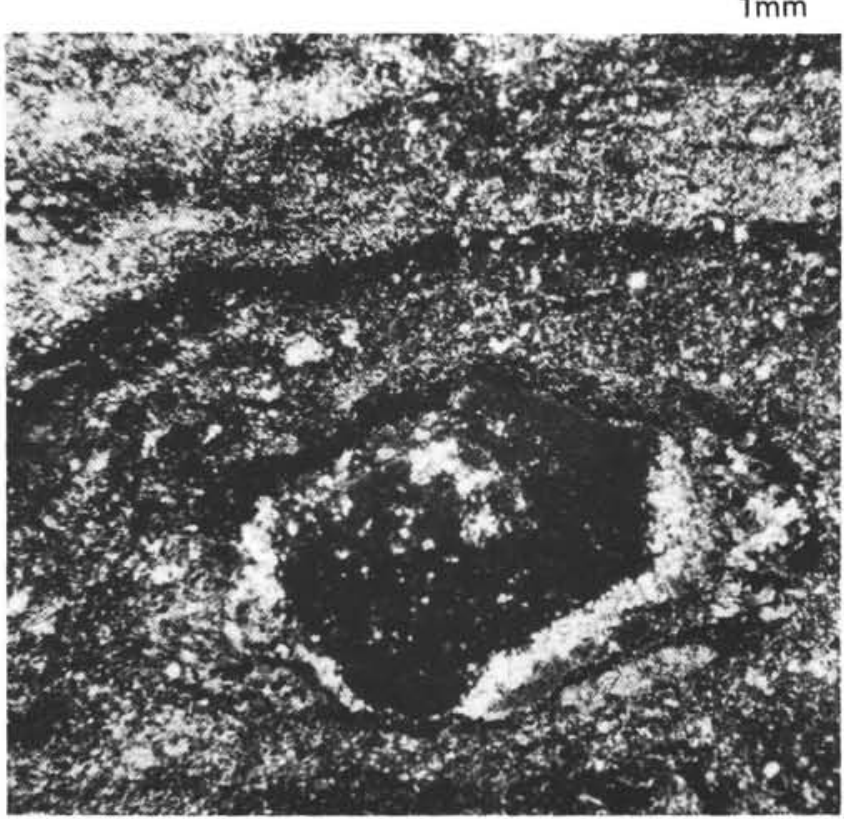

3

$100 \mu \mathrm{m}$

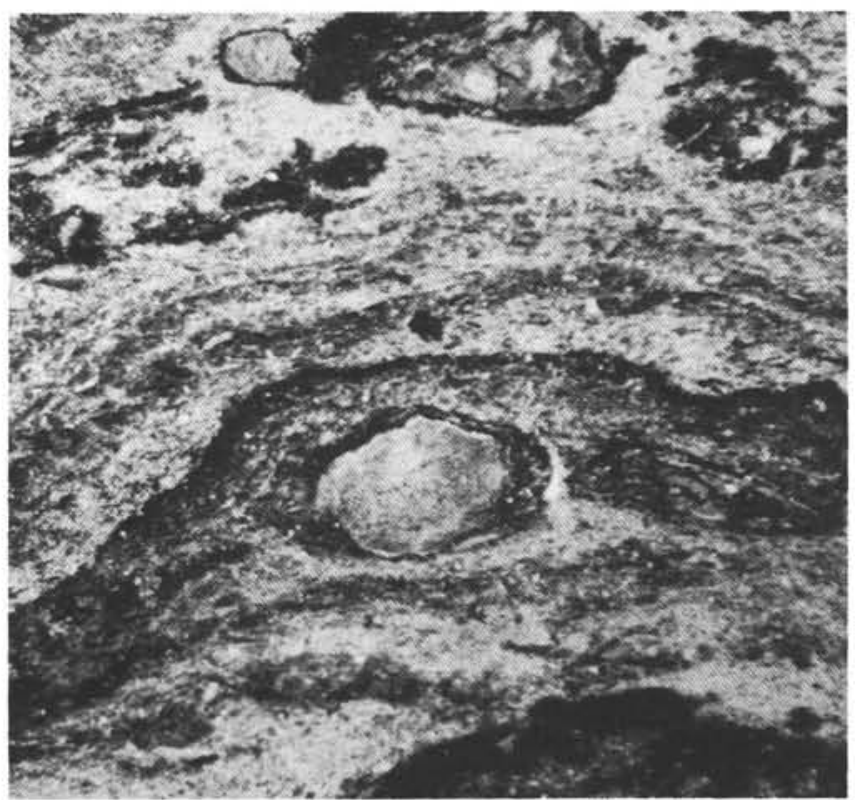

2

$250 \mu \mathrm{m}$

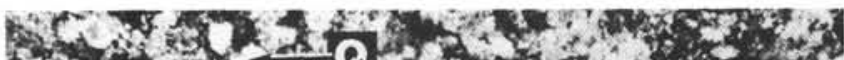

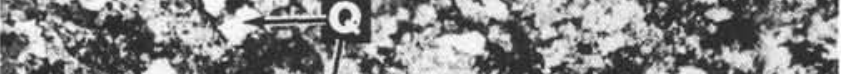

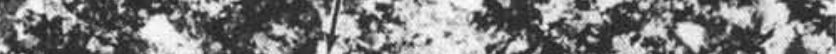

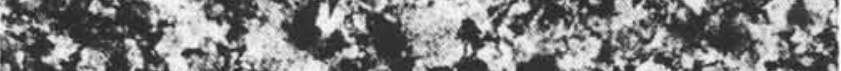

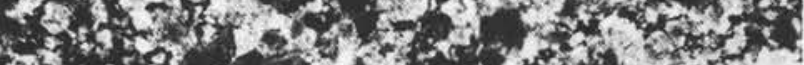

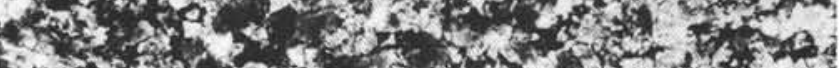

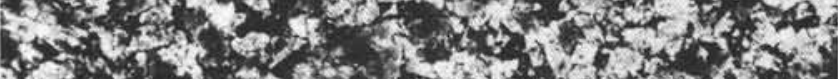

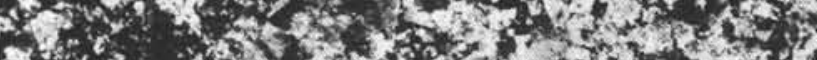
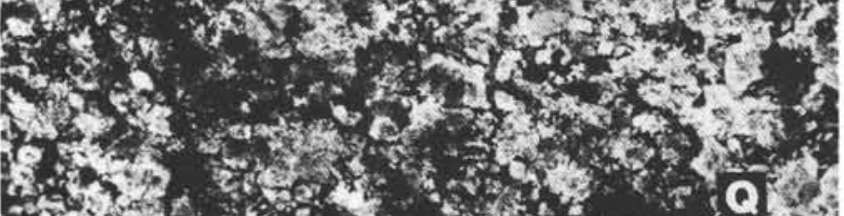

-
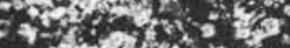

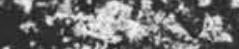

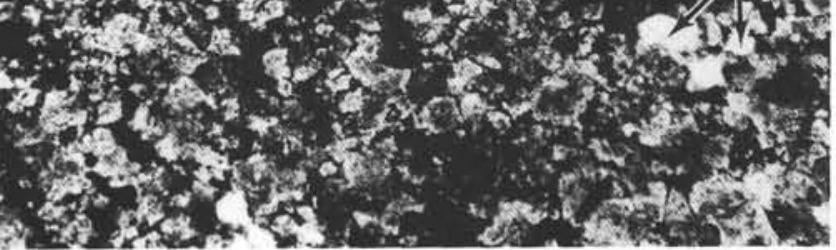

Lit $1 x^{2}$

4

\section{$250 \mu \mathrm{m}$}

Plate 1. Thin-section photomicrographs of dolomites from Galinaute dive Site 1 and the lower sequence from dive Site 2. 1. Sample 86-1-3. Epigenetic dolomite. Note ghost of crinoids and bioclasts. Plane-polarized light. 2. Sample 86-2-2. Silicified dolomite. Note subrounded dolomite clasts within a laminated cherty matrix. Plane-polarized light. 3. Close-up of Figure 2, showing nonchertified dolomite clast in chert-sericite matrix and dark, opaque-rich exsolution laminae and rims. Crossed nicols. 4. Sample 86-2-3. Quartz-bearing epigenetic dolomite. Plane-polarized light. Q = quartz. 


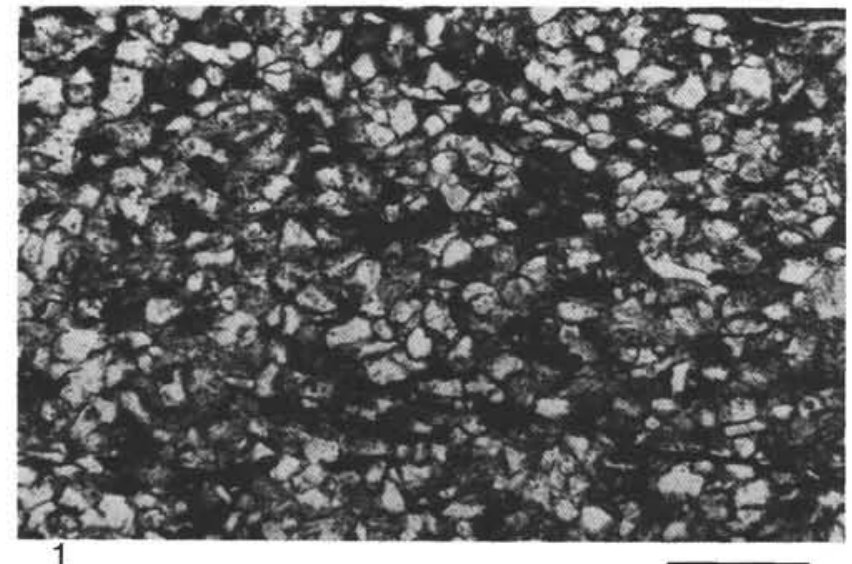

$250 \mu \mathrm{m}$
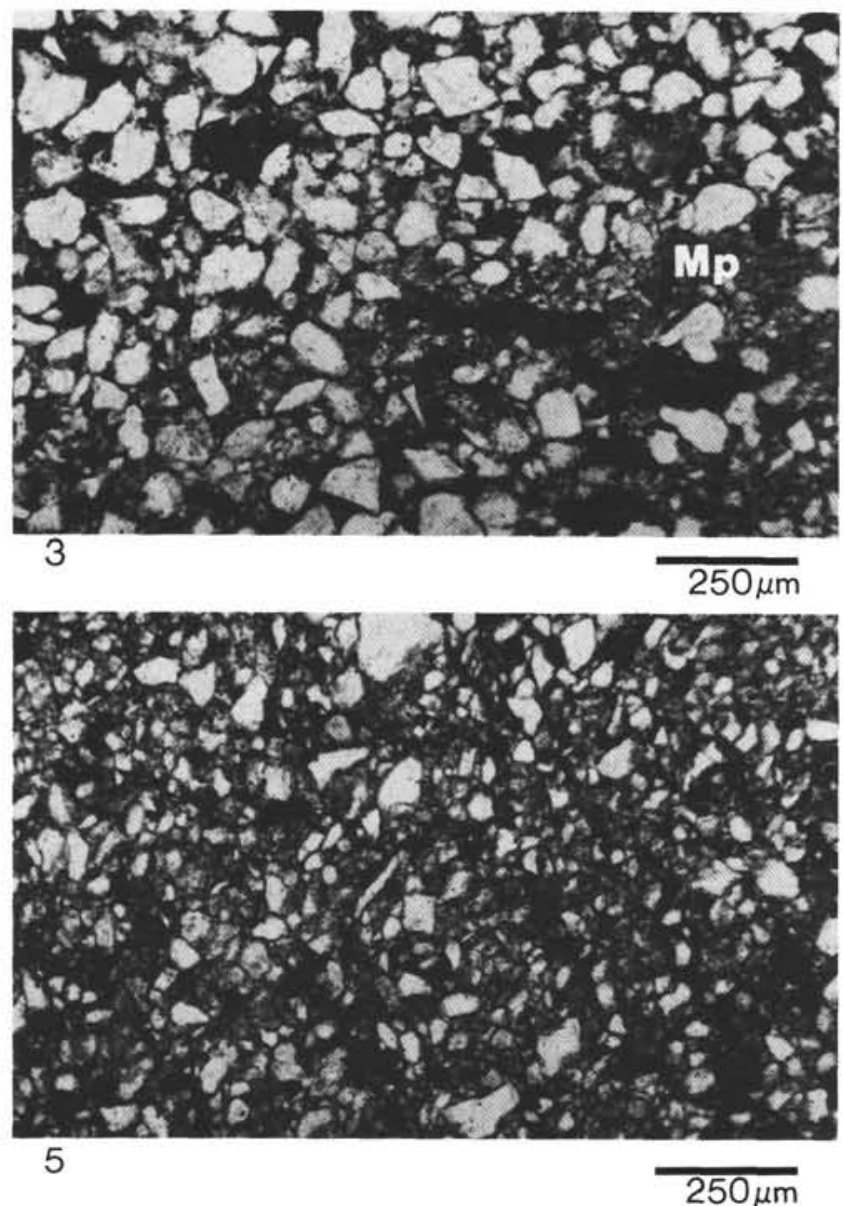
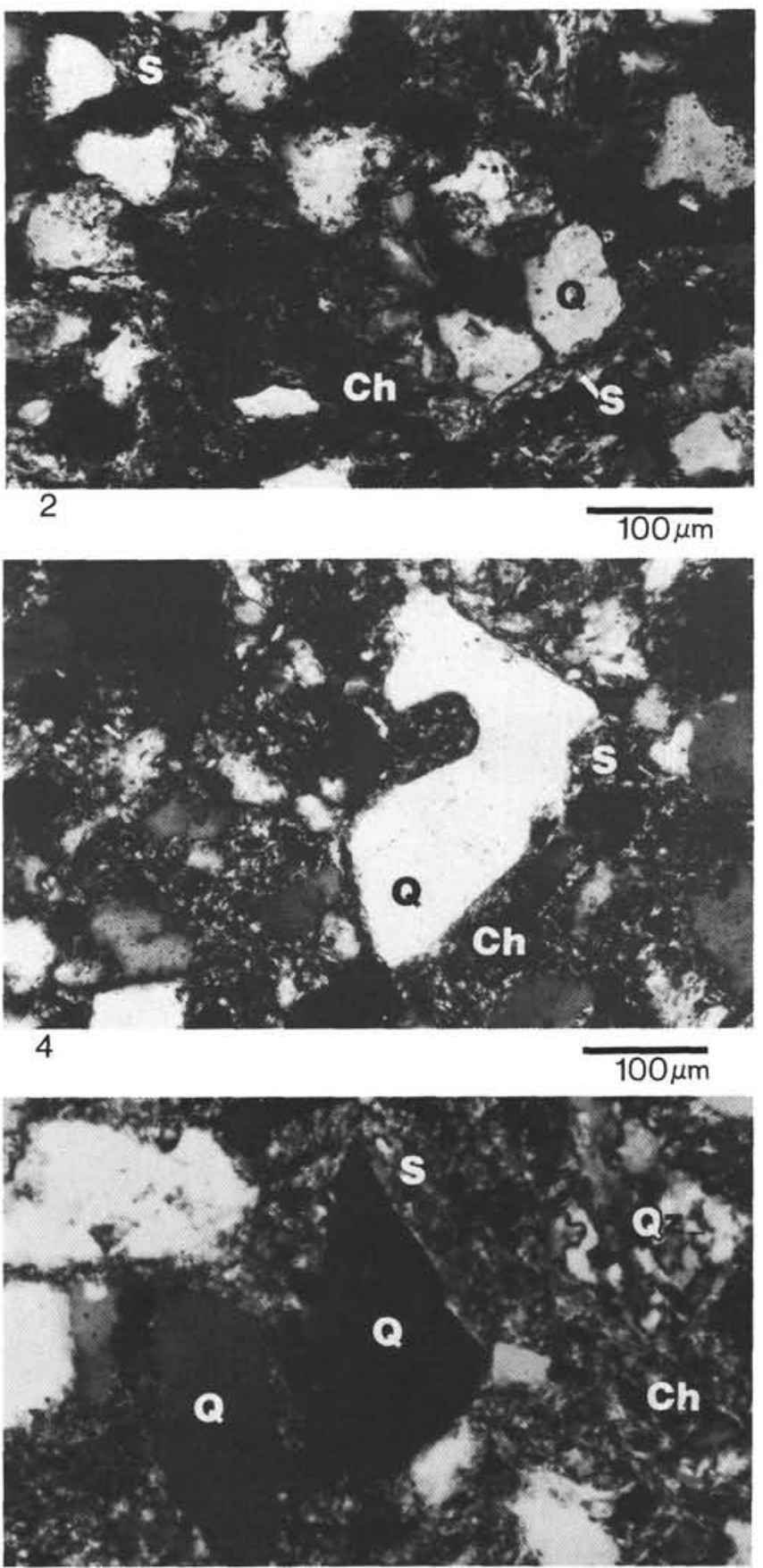

6

a

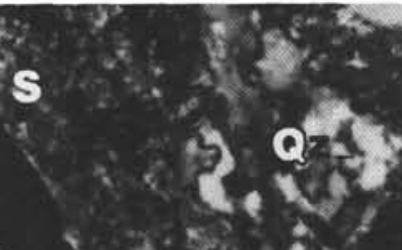

$\mathrm{Ch}$

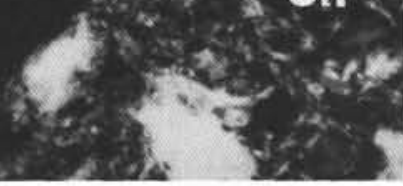

$100 \mu \mathrm{m}$

Plate 2. Thin-section photomicrographs of sandstones from dive Site 2. Q $=$ quartz, $\mathrm{Ch}=$ chlorite, $\mathrm{S}=$ sericite, $\mathrm{Qz}=$ quartzite, $\mathrm{Mp}=$ metapelite fragment. 1. Sample 86-2-1. Fine-grained quartz wacke consisting of angular poorly sorted quartz and minor feldspar, and detrital micas in chlorite matrix. Plane-polarized light. 2. Close-up of Figure 1, showing quartz grains bounded by authigenic chlorite and minor sericite. Crossed nicols. 3. Sample 86-2-4. Fine-grained quartz-rich graywacke, consisting of angular-to-subangular quartz, feldspar, detrital mica, and metapelite grains in a chlorite-sericite matrix. Plane-polarized light. 4. Close-up of Figure 3. Note quartz grain that is probably volcanic in origin. Crossed nicols. 5. Sample 86-2-5. Very fine-grained quartzose graywacke, composed chiefly of poorly sorted quartz and feldspar in a sericite-chlorite matrix with minor quartz cement. Plane-polarized light. 6. Close-up of Figure 5. Note very angular quartz and metapelite grains, bounded by secondary sericite and chlorite. Crossed nicols. 

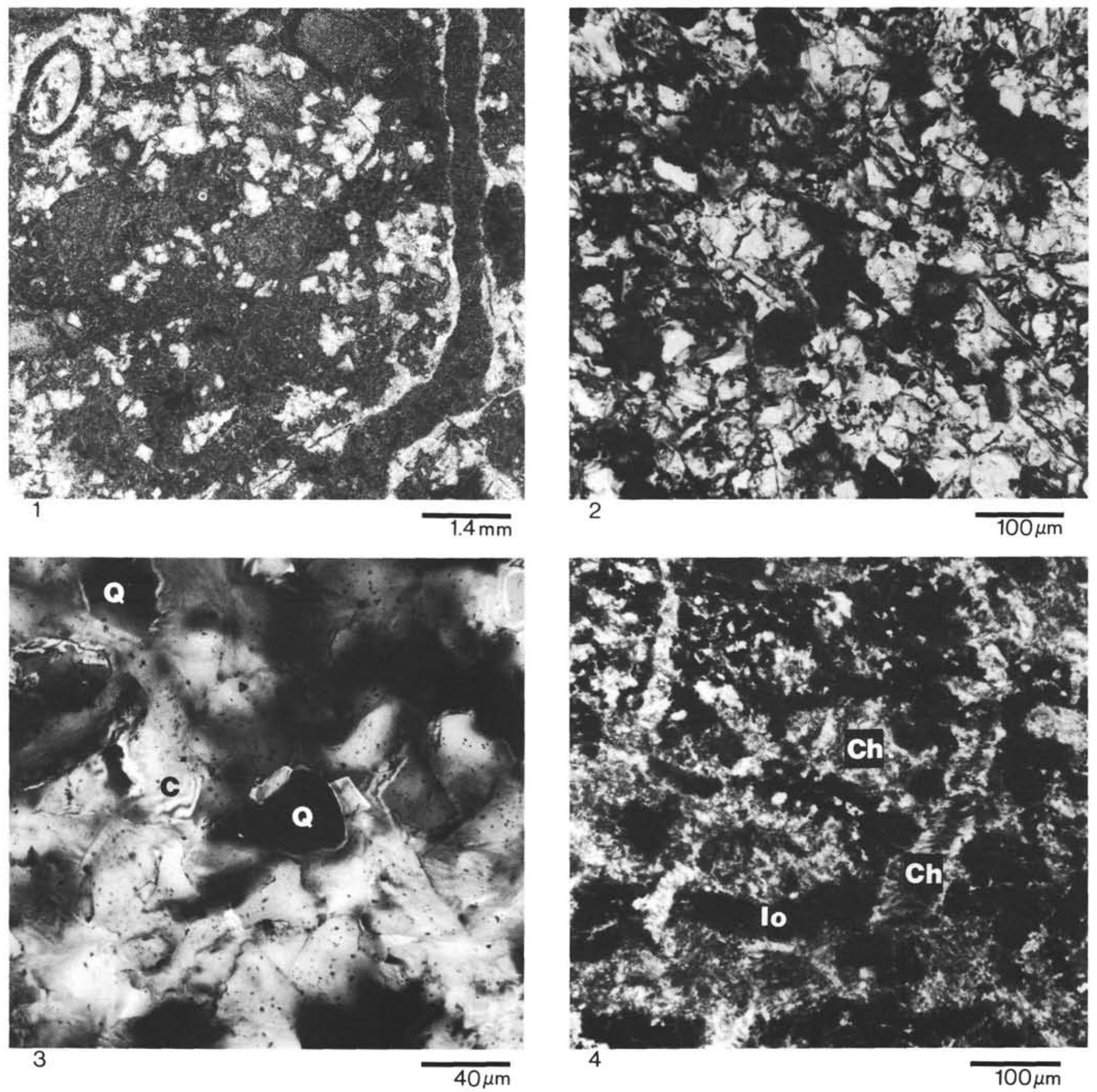

Plate 3. Thin-section photomicrographs of lithologies from the upper sequence at dive Site 2 (Tithonian-Lower Cretaceous?) and underlying "red beds" at dive Site 3. 1. Sample 86-2-7. Coarse crystalline dolomite showing dirty, zoned, dolomite rhombs and ghosts of crinoids, clasts, and bioclasts. Note intercrystalline porosity and fractures filled by clear dolomite. Negative print. 2. Sample 86-2-8. Fine-grained quartzose sandstone. Note carbonate-cemented angular quartz grains and iron oxide pelloids. Plane-polarized light. 3. Close-up of Figure 2, corroded margins and ghost remains of quartz within calcite denote strong replacement of silica by carbonate. Crossed nicols. $\mathrm{Q}=\mathrm{quartz}, \mathrm{Ca}=\mathrm{calcite}$. 4. Sample 86-3-2. Dark red ferruginous crust. Note authigenic chlorite and ferroan chlorite within iron oxides. Crossed nicols. Ch $=$ chlorite, Io $=$ iron oxides. 


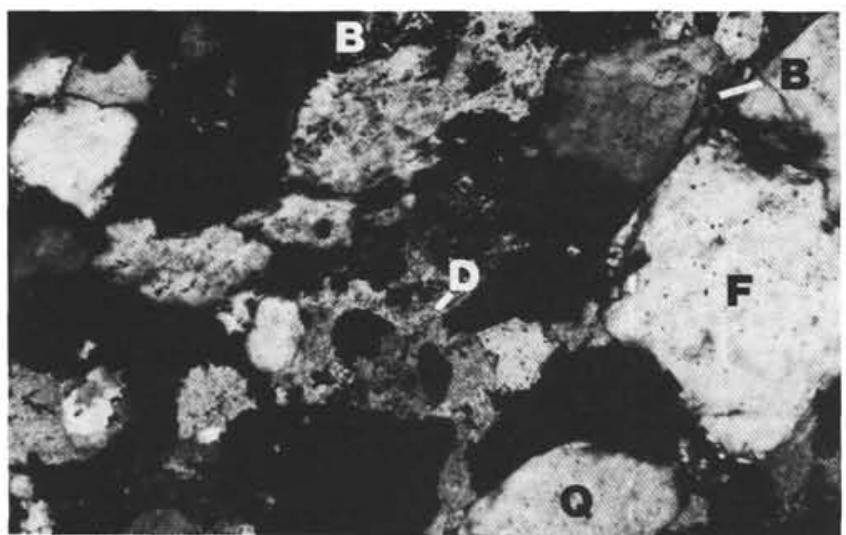

1

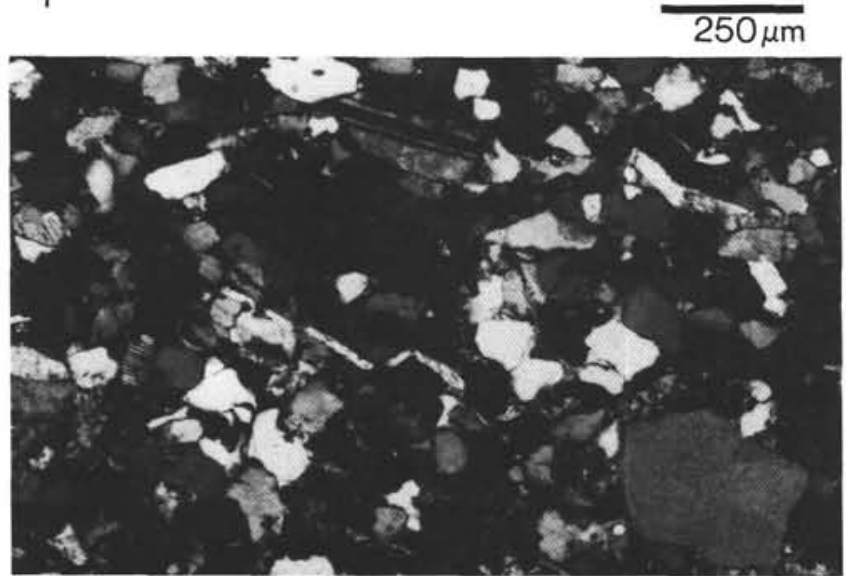

3

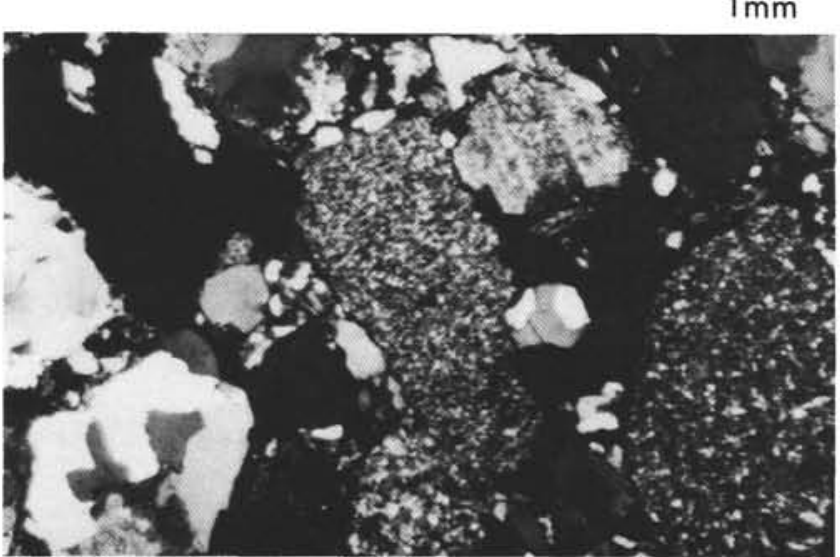

5

$1 \mathrm{~mm}$

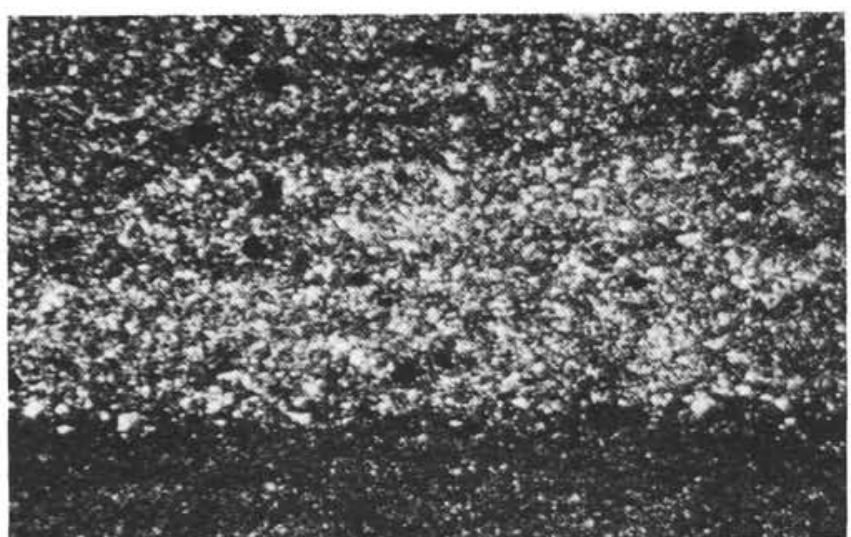

2

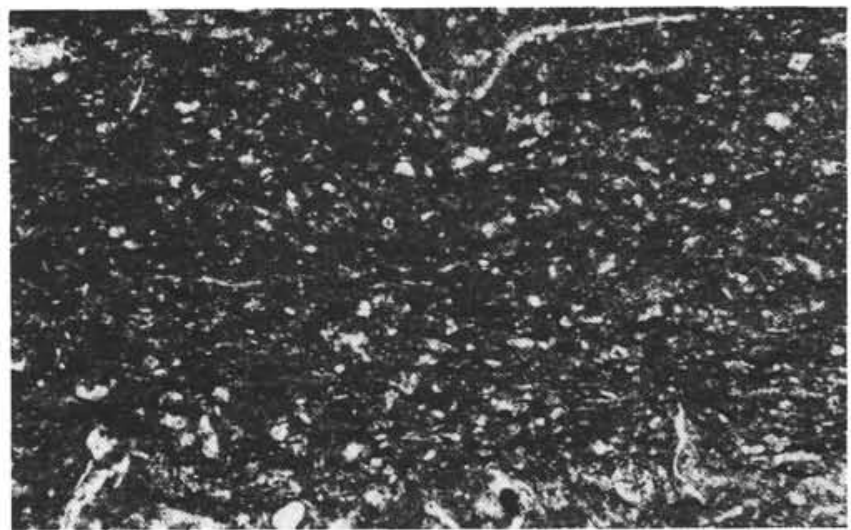

4

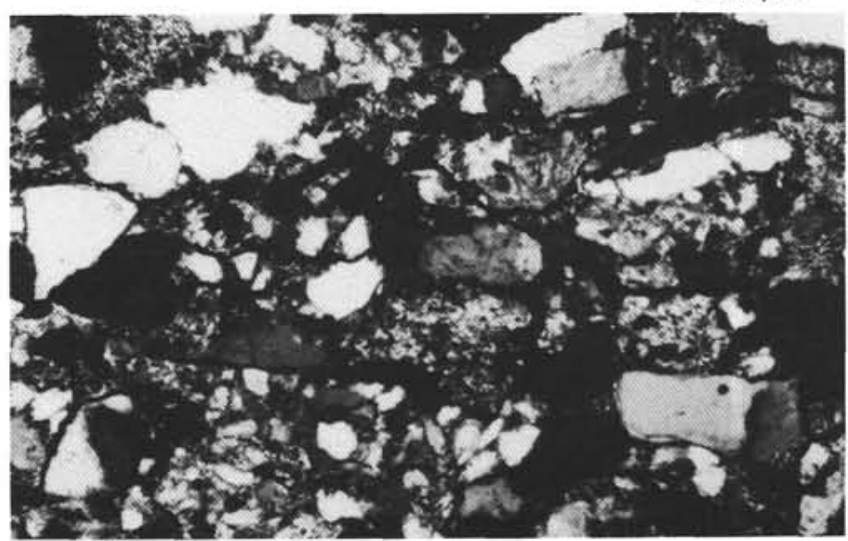

6

$250 \mu \mathrm{m}$

Plate 4. Thin-section photomicrographs of lithologies at dive Sites 5, 7, 8, and 11. 1. Sample 86-5-3. Poorly carbonate-cemented feldspathic arenite. Crossed nicols. $\mathrm{Q}=$ quartz, $\mathrm{F}=$ feldspar, $\mathrm{D}=$ dolomite, $\mathrm{B}=$ biotite. 2. Sample 86-7-3. Fine-grained, quartz-bearing dolomite. Note parallel lamination and weak grading. Plane-polarized light. 3. Sample 86-8-5. Arkosic arenite. Consists mainly of moderately-sorted quartz and feldspar grains cemented by quartz and iron oxides. High packing density and grain overgrowths denote strong diagenesis or anchimetamorphism. Crossed nicols. 4. Sample 86-11-4. Laminated skeletal-rich (radiolarians, calpionellids, and thin pelecypod shells) lime mudstone. Note skeletal concentration highlighting lamination. Plane-polarized light. 5. Sample 86-11-10. Coarse-grained, poorly cemented litharenite. Note subrounded sandstone and quartzite grains. Crossed nicols. 6. Sample 86-11-11. Poorly sorted, poorly cemented subarkosic arenite, composed mainly of angular quartz and feldspar grains welded by iron oxides and minor quartz cement. Crossed nicols. 